Zuraidah, Che Zarrina \& Chang "Transgenderisme di Malaysia: Pelan

Bimbingan Kembali Kepada Fitrah," Afkār Vol. 20 Issue 2 (2018): 279-322

\title{
TRANSGENDERISME DI MALAYSIA: PELAN BIMBINGAN KEMBALI KEPADA FITRAH DARI PERSPEKTIF PSIKOSPIRITUAL ISLAM
}

TRANSGENDERISM IN MALAYSIA: GUIDE PLAN BACK TO FITRAH FROM ISLAMIC PSYCHOSPIRITUAL PERSPECTIVE

\section{Zuraidah Abdullah*, Che Zarrina Sa'ari** \& Lee Wei Chang ${ }^{* * *}$}

*Department of Educational Management, Planning \& Policy. Faculty of Education. University of Malaya. 50603. Kuala Lumpur. Malaysia.

${ }^{* *}$ Department of `Aqidah \& Islamic Thought. Academy of Islamic Studies. University of Malaya. 50603. Kuala Lumpur. Malaysia.

***Research Promotion Unit, Centre for Research Services. Research Management \& Innovation Complex. University of Malaya. 50603. Kuala Lumpur. Malaysia.

$$
\text { Email: **zarrina@um.edu.my }
$$

DOI: https://doi.org/10.22452/afkar.vol20no2.9

\section{Khulasah}

Hari ini masyarakat dunia umumnya dan masyarakat Malaysia khususnya sedang berhadapan dengan isu yang semakin melonjak dalam hal kecelaruan gender iaitu transgender. Golongan ini muncul dengan persoalan kejantinaan, orientasi seksualiti, psikologi, kognitif dan tingkahlaku yang menimbulkan pelbagai reaksi masyarakat, malah melibatkan soal keagamaan khususnya agama Islam. Secara jelas perlakuan transgender dilarang di dalam Islam apatah lagi apabila ia melibatkan soal penampilan dan orientasi seksualiti. Dari sudut perundangan negara dan konteks sosial juga dapat dilihat bahawa ia tidak dapat diterima sebagai sesuatu yang wajar. Namun, apabila dirujuk kepada perspektif mereka yang terlibat dengan transgender, mereka mengemukakan pelbagai sebab berlandaskan pelbagai aspek yang menonjolkan 
keterlibatan mereka dalam perlakuan transgender. Kajian ini mendapati bahawa golongan transgender khususnya mak nyah yang merupakan responden kajian menjadi tanggungjawab bersama masyarakat untuk mengajak dan membimbing mereka kembali ke fitrah kejadian asal mereka iaitu sebagai kaum lelaki. Usaha-usaha seperti bimbingan kaunseling Islam, psikoterapi Islam, outreach, kem motivasi, bantuan kebajikan sosial dan sebagainya perlu digembelingkan dengan lebih giat lagi dari semua lapisan masyarakat untuk bersama-sama membantu dan membimbing mereka. Usaha-usaha sebegini sangat dituntut berbanding dengan mengenepikan dan tidak mempedulikan mereka dengan harapan mereka boleh berubah untuk kembali ke kehidupan yang diredhai Allah SWT dan diterima dalam masyarakat Malaysia yang berpegang kepada ajaran agama dan tatasusila masyarakat.

Kata kunci: Transgender; fitrah; Islam; bimbingan dan nasihat; Malaysia.

\begin{abstract}
Today the world community in general and the Malaysian community in particular are faced with a rising issue in terms of gender disorder ie transgender. These groups come up with the issues of gender, sexual orientation, psychology, cognitive and behavior that cause various reactions from society, and even involve religious matters, especially Islam. Obviously transgender behavior is prohibited in Islam, especially when it comes to appearance and sexual orientation. From the viewpoint of national legislation and social contexts, it can also be seen that it is unacceptable as being reasonable. However, when referred to the perspective of those involved with transgender, they present various reasons based on various aspects that highlight their involvement in transgender. This study found that transgender people, especially mak nyah, who are the respondents of this study, has become a responsibility of the community to invite and guide
\end{abstract}


them back to their original nature as men. Efforts such as the guidance of Islamic counseling, Islamic psychotherapy, outreach, motivational camps, social welfare assistance and others need to be intensified further from community to jointly assist and guide them. Such efforts are very much demanded rather than ignore them in the hope that they can change and turn back to the Islamic way of life and be accepted by Malaysian society.

Keywords: Transgender; human nature; Islam; guide and advice; Malaysia.

\section{Pengenalan}

Dunia globalisasi selangkah dengan peredaran zaman telah mengubah struktur masyarakat daripada tradisional kepada kompleks bagi mengharungi arus kehidupan yang semakin membangun. Perubahan dalam konteks ini mendorong kepada kewujudan persamaan peranan yang ketara dalam kehidupan masyarakat kini yang menunjukkan sistem egalitarian lebih diperluas dalam ruang konteks peranan yang dimainkan oleh setiap anggota masyarakat. Walau bagaimanapun, masyarakat masih lagi berpegang kepada sistem binari (binary system) dalam melihat bagaimana sepatutnya seseorang lelaki dan wanita itu bertingkah laku dan bertindak bersesuaian dengan anatomi seks yang dimiliki. Hal ini berbeza dengan individu yang menyimpang daripada sistem normal yang digelar 'transgender', yang secara terangan menghadapi kecelaruan gender.

Menyoroti sejarah lalu, isu mengenai transgender telah lama wujud dalam pengetahuan umat Islam apabila alQur'an (sebagai contoh Surah al-A'raf 7:80-84) menjelaskan kisah-kisah umat terdahulu yang menjalani kehidupan yang bertentangan dengan fitrah. Cara hidup dan tuntutan kumpulan tersebut yang jelas bersalahan dengan prinsip agama Islam dan nilai moral masyarakat berperadaban mulia semakin berkembang dan 
menimbulkan pelbagai isu yang hangat dibincangkan termasuk di Malaysia.

Merujuk dunia akademia, isu berkenaan dengan transgender ini mula diperkatakan oleh Magnus Hitschfeld (1869-1935) di dalam bukunya yang bertajuk, "The Transvestites: An Investigation of the Erotic Desire to Cross Dress". Istilah trans iaitu tukar atau silang pula dikatakan bermula sekitar era 1960-an oleh Virginia Prince. ${ }^{1}$ Pada ketika itu, istilah transeksual merujuk kepada golongan transgender yang telah dipopularkan oleh Dr Harry Benjamin. ${ }^{2}$ Istilah ini dikatakan mula popular sekitar era 1970-an dan semakin diperluaskan pada tahun-tahun seterusnya yang menegaskan bahawa terdapat individu yang merasa tidak selesa dengan jantina semulajadinya dan lebih selesa memperkenalkan identiti diri sebagai jantina yang difikirkan dalam minda mereka. ${ }^{3}$ Transgender merupakan individu yang merasakan bahawa mereka terperangkap dalam tubuh badan yang berlawanan dengan naluri dan perasaan mereka dan menjurus kepada menjadi jantina yang berlainan dengan jantina kelahiran mereka. ${ }^{4}$

${ }^{1}$ Chang Lee Wei, Azizan Baharuddin, Raihanah Abdullah, Zuraidah Abdullah \& Kathleen Por Chhe Ern, "Transgenderism in Malaysia," Journal of Dharma 37(1) (January-March 2012), 82.

${ }^{2}$ H. Benjamin, The Transsexual Phenomenon: A Scientific Report on Transsexualism and Sex Conversion in the Human Male and Female (New York and London: The Julian Press Inc. 1996).

${ }^{3}$ Chang Lee Wei et al., "Transgenderism in Malaysia," 83; Victoria Clarke, "Resistance and Normalization in the Construction of Lesbian and Gay Families: A Discursive Analysis," Lesbian and Gay Psychology: New Perspectives, eds. Adrian Coyle \& Celia Kitzinger (Oxford: BPS Blackwell, 2002), 98-116.

4 PFlag Canada Inc., "Understanding My Gay, Lesbian or Bisexual Parent," https://mycourses.mcgill.ca/ webct (2006); American Psychological Association, Answers to Your Questions About Transgender People, Gender Identity and Gender Expression, http://www.apa.org/topics/sexuality/transgender.pdf (2011). 
Mendalami pernyataan tersebut, Azizi Yahaya dan Jamaludin Ramli ${ }^{5}$ menjelaskan bahawa masalah ini berlaku disebabkan oleh kecelaruan gender yang dialami kerana mereka mempunyai konflik ketidakserasian antara anatomi seks dan identiti yang difikirkan oleh mereka. ${ }^{6}$ Gender merujuk kepada sifat-sifat yang telah dikonstruksikan apabila menjelaskan berkenaan dengan lelaki dan wanita, sekaligus memberikan gambaran bagaimana seharusnya seseorang lelaki atau wanita itu bertingkah laku selari dengan jantina semula jadi mereka. ${ }^{7}$ Walau bagaimanapun, konflik kecelaruan gender dalam diri ini secara tidak langsung mendorong seseorang itu mewujudkan status identiti yang diinginkannya, sekaligus bertentangan dengan standard piawaian 'normal' masyarakat. ${ }^{8}$

Tambahan pula budaya dan norma masyarakat sendiri telah menggariskan bagaimana sepatutnya seseorang itu bertingkah laku meliputi cara bercakap, berpakaian dan berketerampilan dalam kehidupan mereka bersesuaian dengan jantina yang dimiliki. ${ }^{9}$ Justeru, dapat difahami golongan transgender ini merupakan golongan yang terkeliru mengenai jantina mereka secara emosi sehingga mewujudkan identiti diri yang berbeza dengan orientasi asal seksualiti mereka samada lelaki mahupun wanita,

5 Azizi Yahaya \& Jamaludin Ramli, Psikologi Abnormal (Skudai: Universiti Teknologi Malaysia, 2007), 45-55; Roseliza Murni Ab.

Rahman, "Kecelaruan Identiti Jantina: Perspektif Psikososial dan Biologi," Jurnal Psikologi dan Pembangunan Manusia. Bil. 19 (2003), 41-57.

${ }^{6}$ Roseliza Murni Ab. Rahman, "Kecelaruan Identiti Jantina: Perspektif Psikososial dan Biologi," Jurnal Psikologi dan Pembangunan Manusia 19 (2003), 41-57.

7 Wan Halim Othman, "Dilema Mak Nyah di dalam Masyarakat Malaysia," (Kertas Kerja Seminar Mak Nyah, Universiti Malaya, 2425 Oktober 1987).

8 J.S. McKinney, "On the Margins: A Study of the Experiences of Transgender College Students," Journal of Gay \& Lesbian Issues in Education 3(1), (2005), 63-76.

9 Wan Halim, "Dilema Mak Nyah di dalam Masyarakat Malaysia". 
malah berkesanggupan berusaha mengubah jantina melalui pembedahan atau penggunaan hormon. Golongan ini bukanlah mereka yang dilahirkan sebagai khunsa (interseks) yang mengalami masalah alat reproduksi, organ pembiakan luaran atau dalaman, mahupun hormon dan kromosom. ${ }^{10}$

Fenomena transgender juga turut bertapak di Malaysia sehingga terdapat pelbagai organisasi dan pertubuhan yang ditubuhkan secara tersusun dan terancang. Perkembangan perkara ini semakin rancak apabila golongan ini diberi pendedahan mengenai hak-hak mereka (human rights) seperti mana hak yang diperolehi golongan ini di negaranegara luar. Justeru, pelbagai isu dan masalah timbul akibat tuntutan hak oleh golongan ini. Sejajar dengan perkembangan kumpulan-kumpulan transgender di Malaysia, maka timbullah beberapa isu yang mengancam nilai agama dan akhlak masyarakat Islam hari ini. Antara isu utamanya ialah perlakuan transgender adalah bertentangan dengan ajaran agama Islam sebagai agama Persekutuan.

\section{Naluri, Akal dan Fitrah Manusia Berlandaskan Agama Islam}

Agama Islam melarang apa juga bentuk paksaan untuk berada dalam agama, namun ketika seseorang melafazkan syahadah secara sedar dan faham kesannya, maka dia terikat dengan seluruh peraturan Islam. Ini jelas ditegaskan dalam al-Quran: ${ }^{11}$

\footnotetext{
${ }^{10}$ Norafifah binti Ab Hamid, Nor Azlina binti Abd Wahab, Norajila binti Che Man, Mohd Nazim bin Ganti Shaari \& Pg Ismail bin Pg Musa, "Gejala Transgender di Malaysia: Sorotan Awal Kajian dari Perspektif Islam dan Undang-undang," Jurnal Penyelidikan Islam 27 (2015), 2; Zubaidi Hj Ahmad, "Perbezaan Khunsa \& Transeksual," Majalah I 147 (2015), 26.

${ }^{11}$ Surah al-Kahf 18:29.
} 


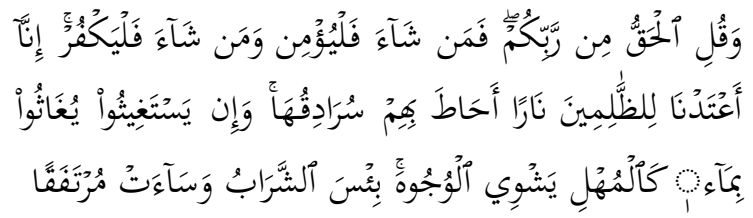

Terjemahan: Dan katakanlah (wahai Muhammad): Kebenaran itu ialah yang datang daripada Tuhan kamu, maka sesiapa yang mahu beriman, hendaklah ia beriman; dan sesiapa yang mahu kufur ingkar, biarlah dia mengingkarinya. Kerana Kami telah menyediakan bagi orang yang berlaku zalim itu api neraka, yang meliputi mereka laksana khemah; dan jika mereka meminta pertolongan kerana dahaga, mereka diberi pertolongan dengan air yang seperti tembaga cair yang membakar muka; amatlah buruknya minuman itu, dan amatlah buruknya neraka sebagai tempat bersenang-senang.

Bukan itu sahaja, Allah SWT telah menciptakan manusia dengan memiliki naluri untuk mempertahankan diri dan dengan naluri itulah seseorang manusia sentiasa ingin melindungi maruah diri. Namun, untuk mempertahankan maruah diri tidak boleh dilakukan secara sembarangan menurut kehendak akal manusia sematamata. Akal selalunya dikaitkan dengan rasionaliti. Rasionaliti ialah apa-apa sahaja pendapat yang boleh diterima akal sebagai sumber kepada sesuatu pengetahuan atau sesuatu justifikasi. ${ }^{12}$ Rasionaliti inilah yang selalu digunakan dalam sesuatu penyelidikan.

Penyelidikan merupakan alat untuk memperoleh sumber pengetahuan yang sah dan boleh dipercayai iaitu

12 A.R. Lacey, A Dictionary of Philosophy (London: Routledge, 1996), "rationalism", 286. 
sumber pengetahuan yang saintifik dan logik. ${ }^{13}$ Logik pula secara umumnya ialah sesuatu yang diterima akal. Oleh itu, sesuatu yang rasional iaitu suatu ilmu atau justifikasi yang diberikan mestilah yang boleh diterima akal. Perkara ini dapat dilihat dengan lebih jelas pada takrifan akal mengikut tradisi barat sebagaimana yang disebut dalam Brittanica Encyclopedia sebagai sebuah fakulti yang melibatkan kesedaran, mengingat, mempertimbang, menilai dan menentukan sesuatu.

Akal pada suatu sudut tertentu mencerminkan kejadian-kejadian berikut, iaitu sensasi, persepsi, emosi, memori, kehendak, hujah yang pelbagai jenis, tujuan, pilihan, ciri-ciri personaliti dan ketidaksedaran. Daripada takrifan sebelum ini, dapat disimpulkan bahawa peranan akal terbahagi kepada tiga. Pertamanya mengkaji, menyelidik, menerima maklumat atau ilmu. Kedua, setelah diterima barulah maklumat itu dikumpul, diingat dan disimpan. Pada tahap ini akal berfungsi sebagai khazanah. Ketiga, mengeluarkan ilmu atau maklumat melalui komunikasi rasmi atau tidak. Pada asasnya, Islam juga menerima tiga peranan akal seperti takrifan sebelum ini. Namun akal menurut barat sedikit berbeza dengan Islam. Barat hanya mengiktiraf akal sebagai sumber ilmu pengetahuan dari sudut zahir.

Manakala dalam Islam, selain dari akal dalam takrifan barat dari sudut zahir, masih terdapat sumber lain iaitu sudut batin. Buktinya dapat dilihat daripada beberapa pengertian akal yang menonjolkan sisi batin akal seperti pengertian-pengertian berikut. Menurut al-Jurjāni, ${ }^{14}$ akal ialah jiwa yang diciptakan Allah SWT yang berhubungan dengan badan manusia. Ada juga yang mentakrifkan akal bererti cahaya (nur) dalam hati untuk mengetahui

13 C. Yan Piaw, Kaedah dan Statistik Penyelidikan: Kaedah Penyelidikan (Malaysia: McGraw-Hill Education, 2006).

14 Al-Jurjānī, 'Alì Muhammad al-Sharif, Al-Ta 'rífāt (Beirut: Dār alKutub al-'Ilmiyyah, 2000). 
kebenaran dan kebaikan. ${ }^{15}$ Akal merupakan nur rohani yang diketahui darinya perkara-perkara darūri dan nazarí. ${ }^{16}$ Mukhtar Yahya menyimpulkan akal itu ialah suatu sifat daripada ciri-ciri jiwa (hati). Dengan adanya akal, jiwa dapat mengetahui dan mengenal sesuatu yang $m a$ ' $q \bar{u} l$ (yang dapat difikir) dan maḥsūs (yang dapat dikesan oleh pancaindera). ${ }^{17}$

Daripada pengertian-pengertian yang telah dibincangkan, dapat difahami bahawa akal merupakan cahaya (nur) dalam kalbu (qalb) yang berguna untuk mengetahui kebenaran dan kebatilan, mengatur dan mengendalikan jasmani bersesuaian dengan ajaran agama Islam. Oleh itu, akal bukan hanya mempunyai kekuatan berfikir secara rasional, tetapi akal mempunyai sisi rohani dan mengawal kekuatan berfikir secara rasional serta menentukan tahap tertinggi yang boleh dicapainya. Perkara ini dapat dilihat dengan lebih jelas sekiranya difahami berdasarkan ayat berikut: ${ }^{18}$

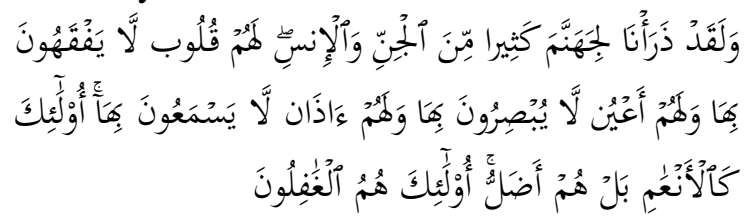

Terjemahan: Dan sesungguhnya Kami jadikan untuk neraka jahanam, ramai dari jin dan

15 Muhammad Taqī al-Mudarrisī, Al-Manțiq al-Islāmī: Ușūluh wa Manāhijuh (Kaherah: Dār al-Bayān li al-Ṭibā 'ah wa al-Nashr, 1992).

${ }^{16}$ Mohamed Safiullah Munsoor \& Che Zarrina Saari, "Knowledge and Islam on the Non-Rational and Rational-Heart-Brain InterConnection: A Classical Islamic Scholarly Perspective," Jurnal Akidah dan Pemikiran Islam (AFKAR), Bil. 19(1) (2017), 134-135.

${ }^{17}$ Mukhtar Yahya, Pertumbuhan Akal dan Memanfaatkan Naluri KanakKanak (Jakarta: Bulan Bintang, 1972); Che Zarrina Saari \& Mohd Manawi Mohd Akib, "Beberapa Persoalan Berkaitan Konsep Insan menurut Fakhr al-Din al-Razi," Jurnal Akidah dan Pemikiran Islam (AFKAR), Bil. 19 (Special Issue) (2017), 87-114.

${ }^{18}$ Surah al-A'raf 7:179. 
manusia yang mempunyai hati, (tetapi) tidak mahu memahami dengannya (ayat-ayat Allah), dan yang mempunyai mata (tetapi) tidak mahu melihat dengannya (bukti keesaan Allah) dan yang mempunyai telinga (tetapi) tidak mahu mendengar dengannya (ajaran dan nasihat); mereka itu seperti binatang ternak, bahkan mereka lebih sesat lagi; mereka itulah orangorang Yang lalai.

Ayat di atas menunjukkan bahawa setiap manusia itu ada akal dan kalbu yang berperaturan dan dapat menilai baik dan buruknya yang apabila berada dalam tahap jiwa murni tidak akan bertentangan dengan kehendak Allah SWT sebagai Pencipta. Justeru, makna diri manusia harus didasarkan kepada peraturan Allah SWT.

Allah SWT menciptakan manusia dan diizinkan fitrah manusia untuk tertarik kepada jantina yang berlawanan secara semula jadi. Allah SWT menciptakan manusia hanya terdiri daripada dua jenis untuk melahirkan keturunan, maka hanya dengan pernikahan antara lelaki dan perempuan merupakan jalan yang benar dan diperakui. ${ }^{19}$ Namun, gejala perlakuan dan tabiat yang bertentangan dengan sistem kehidupan normal seseorang manusia hari ini telah menjadi suatu perkara yang biasa di dunia amnya dan Malaysia khasnya yang dianggap sebagai melanggar fitrah.

Fitrah dengan erti agama yang benar, iaitu agama Allah SWT, yang dihubungkan sebahagian penafsir alQur'an dengan kata fitrah dalam surah al-Rum ayat 30 yang ertinya: "Maka hadapkanlah wajahmu dengan lurus kepada agama Allah; (tetaplah atas) fitrah Allah yang telah menciptakan manusia menurut fitrah itu, tidak ada perubahan pada fitrah Allah. (Itulah) agama yang lurus;

${ }^{19}$ Norafifah et al., "Gejala Transgender di Malaysia”, 3-4. 
tetapi kebanyakan manusia tidak mengetahui". ${ }^{20}$ Ada juga yang mentafsirkan agama yang lurus (benar) di sini sebagai agama Islam, dengan alasan Islam adalah agama yang sesuai dengan fitrah manusia. Islam adalah agama fitrah kerana sesuai dengan keperluan manusia untuk tunduk kepada Tuhan, dan dapat membimbing manusia kepada cara beribadah yang benar. Fitrah juga diertikan sebagai sunnah Nabi Muhammad SAW, dan juga yang mengertikannya dengan sunnah para nabi. ${ }^{21}$

Peraturan dan fitrah ini tidak hanya ditentukan kepada manusia, malah kepada binatang dan tumbuh-tumbuhan. Tiada dalam sejarah dunia, seekor binatang mencari jantina sesama jenis begitu juga tumbuh-tumbuhan. Tetapi sejarah manusia telah mencatatkan sejarah tingkah laku di luar tabi'i ini dan melanggari fitrah sepertimana yang berlaku di zaman Nabi Lut a.s sehingga Allah SWT telah menurunkan bala yang dahsyat disebabkan oleh kerosakan dan maksiat yang dilakukan oleh manusia pada ketika itu. Umat Nabi Lut a.s. adalah manusia yang derhaka dan bersikap jahat dan keji yang gemar melakukan perkara mungkar termasuk berhubungan dengan sesama jenis. ${ }^{22}$

Perlakuan transgender ini jelas haram di sisi Islam berdasarkan pelbagai dalil yang dinyatakan di dalam alQur'an, Hadith dan juga ijma' ulama. ${ }^{23}$ Justeru, perlu

20 'Abdullah Yusuf 'Ali, The Meaning of the Holy Qur'ān (Maryland: Amana Publication, 1997), 1016.

${ }^{21}$ Dewan Redaksi, Ensiklopedi Islam (Jakarta: Ichtiar Baru Van Hoeve, 2001), 21.

${ }^{22}$ Surah al-Naml: 54-55.

23 Antaranya, Surah al-A'raf 7;80-81; Surah al-Shu'ara' 26:165-166; Surah al-An'am 6:85-87; Surah Sad 38:11-14; Surah al-Qamar 54:3340; Aḥmad bin Hanbal Abū 'Abd Allāh al-Shaybānī, Musnad al-Imām Ahmad Bin Hanbal, no. hadith 10460 (Kaherah: Mu'assasah Qurțubah, t.t.) 1:497; Abū Bakr Aḥmad bin al-Ḥusayn al-Bayhaqī, Shu'ab al-Imān, tahqiq. Muhammad al-Sa'ìd Basyūnì Zaghlūl (Beirut: Dār al-Kutub al-'Alami, 1410H), 7:324. Aḥmad bin 'Alī bin Hajar al-'Asqalāni, Fatḥ al-Bārì bi Sharh Sahịh al-Imām Abì 'Abd Allāh Muhammad bin Ismā'ìl al-Bukhārì, tahqiq. 'Abd al-Qādir 
ditegaskan Islam memandang isu melakukan perubahan kepada diri atau badan sebagai perkara yang bercanggah dengan agama Islam. Pembedahan untuk menukar jantina sama ada daripada lelaki kepada perempuan atau sebaliknya sudah pasti dilarang sama sekali. ${ }^{24}$ Oleh yang demikian, para ulama menegaskan Islam telah mengemukakan garis panduan yang jelas tentang aspek kejantinaan sehinggakan perkara yang mungkin menyamai jantina lelaki atau wanita sama ada dari sudut perwatakan, cara berpakaian, bertingkahlaku apatah lagi fungsi dan peranan seseorang individu yang mewakili jantina tertentu dianggap sebagai menyalahi atau bertentangan dengan orientasi agama. ${ }^{25}$

Bukan itu sahaja, selain berperilaku dan berpenampilan seperti berlawanan jenis, ada dalam kalangan transgender yang mengambil keputusan untuk menggantikan jenis kelamin mereka melalui pembedahan jantina mahupun mengubah diri mereka dengan mengambil atau menyuntik hormon. Jawatankuasa Fatwa Majlis Kebangsaan Bagi Hal Ehwal Agama Islam Malaysia yang bersidang kali ke-4 pada 13 hingga 14 April 1982 telah

Shaybah al-Hamad (Saudi Arabia: Maktabah al-Malik Fahad alWațaniyyah, 2001), 10:345. Ijma' ulama bersepakat bahawa perlakuan zina, liwat dan musahaqah yang dikaitkan dengan perlakuan lesbian, gay, biseksual adalah termasuk dalam dosa besar dan pelakunya wajib bertaubat. Ulama juga sependapat bahawa homoseksualiti suatu jenayah yang boleh dikenakan hukuman demi menjaga kepentingan diri dan masyarakat. Walau bagaimanapun, perbezaan pandangan timbul mengenai bentuk hukuman sama ada hudud atau dibuang negeri. Lihat Nik Muhd Marzuki $\mathrm{Hj}$. Mohd D. Nor, Laporan pembentangan wakil JAWI di perjumpaan berkenaan lesbian, maknyah, biseksual dan trangender (transgender) dari sudut pandangan Islam bersama SUHAKAM, 2011.

24 Norliah Sajuri, "Pertukaran Status Jantina dalam Mykad dan Impikasinya," Jurnal Penyelidikan Islam, bil. 19 (2006), 118.

${ }^{25}$ Keputusan Muzakarah Jawatankuasa Fatwa Majlis Kebangsaan Bagi Hal Ehwal Ugama Islam Malaysia Mengenai Isu-Isu Sains Dan Perubatan (Kuala Lumpur: Jabatan Kemajuan Islam Malaysia, 2010), 8. 
membincangkan pertukaran jantina dan memutuskan bahawa: ${ }^{26}$

a. Pertukaran jantina dari lelaki kepada perempuan atau sebaliknya melalui pembedahan adalah haram dari segi syarak.

b. Seseorang yang dilahirkan lelaki, hukumnya tetap lelaki walaupun berjaya ditukarkan jantinanya melalui pembedahan.

c. Seseorang yang dilahirkan perempuan, hukumnya tetap perempuan walaupun berjaya ditukarkan jantinanya melalui pembedahan.

d. Seseorang yang dilahirkan 'khunsa musykil' iaitu manusia yang dilahirkan mempunyai dua alat kemaluan lelaki dan perempuan, diharuskan melakukan pembedahan bagi mengekalkan salah satu alat jantina yang benar-benar berfungsi dan dapat digunakan mengikut keadaan yang sesuai.

Fenomena seperti ini sudah pasti menjadikan seseorang itu terkeluar dan melencong daripada fitrahnya. Oleh itu, Islam memandang isu melakukan perubahan kepada diri atau badan yang melibatkan kejantinaan sebagai perkara yang bercanggah dengan agama Islam. Menukar jantina asal bererti merubah kejadian fitrah ciptaan Allah $\mathrm{SWT}^{27}$ yang menolak maslahah dan mengundang mudarat kepada diri sendiri dan orang lain.

\section{Penolakan Perlakuan Tidak Bermoral dan Zina Dari Perspektif Islam dan Pelbagai Agama}

Agama dan moral (kebaikan) tidak dapat dipisahkan, termasuk dalam interpretasi hak dan kewajipan asasi manusia. Semua agama, nilai moral dan budaya dunia berkongsi etika selari (parallel ethics) dalam ruangan yang cukup luas seperti pentingnya mempunyai bersifat jujur dan

26 Norliah Sajuri, "Pertukaran Status Jantina Dalam Mykad dan Impikasinya," 118.

${ }^{27}$ Surah al-Nisa' 4:119. 
amanah dan buruknya judi, arak dan zina (heteroseksual dan homoseksual; sukarela atau paksaan). Pertimbangan agama ini didasarkan kepada al-Quran, Injil, Vedas, Tripitaka, Adi Granth dan lain-lain teks autoriti tertinggi agama dalam pelbagai disiplin ilmu (epistemologi) dalam sistem nilainya (aksiologi) yang unik dan berbeza. Sesetengan teks agama atau tradisinya seperti Buddha tiada sebutan khusus tentang homoseksual. Namun prinsip, konsep dan nilai dalaman agama tersebut dengan sendirinya dapat difahami menolak homoseksual.

Terdapat tradisi dalam agama yang mentakrifkan zina sebagai persetubuhan melalui qubul dan dubur, di mana turut merangkumi hubungan sama dan beza jantina (heteroseksual dan homoseksual). Terdapat juga yang membezakannya dengan pengertian zina hanya berlaku melalui qubul melibatkan jantina berbeza (heteroseksual). Namun, asas dan prinsip semua agama tidak kabur atau berbeza mengenai menolak seks dan seksualiti di luar perkahwinan (non-marital sex) dan ia melawan fitrah menurut majoriti agama. Pengharaman ini disabitkan dengan teks agama yang jelas, antaranya seperti:

i. Islam: ${ }^{28}$

a. Al-Quran: Zina \& Homoseks [Al-Isra':17-32], [Al-Nur:24-2], [Al-A`raf:80-84], [Al-Naml:5458], [Al-Nisa':15-16], [Al-Ankabut: 28-35].

b. Hadith: Zina \& Homoseks; [Sunan Tirmidhi, Hadith no. 1377; Sunan Ibn Majah, Hadith no. 2553] [Sunan Abi Dawud, Hadith no. 3869], [Musnad Imam Ahmad, Hadith no. 2677].

c. Ijmak: Islam dan semua mazhabnya bersepakat (konsensus) mengharamkan seks luar perkahwinan atau zina (heteroseksual dan homoseksual) dengan metodologi dalil qat $i$ (explict/basic tenet of religion). Dalil juga jelas mensyariatkan hukuman atas pelakunya, namun

28، Abdullah Yusuf 'Ali, The Meaning of the Holy Qur'an. 
bersifat zanni (implicit/ ancillary branches of religion) mengenai bentuk hukuman sama ada hudud atau takzir. Pelakunya wajib bertaubat.

ii. Kristian: ${ }^{29}$

Bible: Homoseks; [Kejadian 19:4-5], [Imamat 18:22], [Imamat 20:13], [Roma 1:26-27], [Korintus 6:9-10], [1 Timotius 1:9-10], dan [Yudas 1:7].

iii. Hindu: $:^{30}$

Sruti \& Smriti, Zina; [Bhagavadgita 1.41-43], [Vishnu Purana 3.11], [Manusmriti: Chapter 8-9]. Homoseks; [Manusmriti 11:174], [Canto 3].

iv. Buddha: ${ }^{31}$

Tripitaka: Seks/zina (heteroseksual dan homoseksual); [Five Precepts (Panca Sila)], [Parabhava Sutta] dan [Akusala Kamma].

v. Taoisme, Konfusianisme, Yahudi, Jaina dan semua norma masyarakat berdasarkan "nilai moral" turut mengharamkan identiti dan orientasi tidak bermoral seperti kedua-dua bentuk zina ini. Pengharaman ini bersifat tetap (absolute, universal) serta tidak berubah (relative, particular).

Berasaskan agama Islam dan kepelbagaian agama ini jelas sekali perlakuan transgender dianggap suatu kesalahan yang melanggar hukum alam dan fitrah seorang manusia normal yang perlu ditangani oleh masyarakat dan negara.

29 The Holy Bible. Douay-Rheims Version 1609-1582. http://triggs.djvu.org/djvu-

editions.com/BIBLES/DRV/Download.pdf diakses pada $1 \mathrm{hb}$ Disember 2018.

${ }^{30}$ J. Garrett \& H. Wilhelm, eds. The Bhagavat-Geeta or Dialogues of Krishna and Arjoon in Eighteen Lectures (Bangalore: Wesleyan Mission Press, 1849).

${ }^{31}$ Pali Tipitaka, https://www.tipitaka.org/pdf/romn/, diakses pada 4hb Disember 2018. 


\section{Kaedah Kajian}

Bagi memastikan hasil kajian sesuatu penyelidikan itu berlaku dengan baik, penyelidik harus dapat merancang kajiannya dengan menggunakan kaedah yang bersesuaian dengan tujuan kajiannya. Sebagaimana yang dinyatakan oleh Zikmund, reka bentuk kajian merupakan perancangan yang khusus bagi kaedah dan prosedur untuk mengumpul dan menganalsis sesebuah data. ${ }^{32}$ Ini adalah kerana reka bentuk kajian melibatkan proses membuat keputusan dan pilihan yang berpandukan kepada tujuan kajian, strategi kajian, tempat kajian, jenis kajian, unit analisis, reka bentuk persampelan, kaedah pengumpulan data, pengukuran dan penganalisisan data. Kajian ini merupakan kajian tinjauan yang bertujuan mengumpul data daripada satu set populasi. Menurut Barbie, kajian tinjauan merupakan kaedah yang terbaik untuk memungut data yang asli daripada populasi yang besar melalui teknik persampelan. ${ }^{33}$ Data untuk kajian ini diperoleh melalui soal selidik dan temu bual.

Kajian ini menggunakan pendekatan kaedah reka bentuk penyelidikan gabungan penjelasan yang dikenali sebagai "QUAN-qual" yang menggabungkan kaedah kuantitatif dan kualitatif. Tujuan pengkaji mengaplikasikan dua kaedah penyelidikan ini adalah untuk membina kekuatan dan sinergi yang wujud di antara kedua-dua kaedah tersebut yang dilihat mampu memberi pemahaman terhadap sesuatu fenomena dengan lebih jelas jika dibandingkan dengan menggunakan hanya satu kaedah penyelidikan sahaja seperti dinyatakan oleh Gay, Mills dan Airasian. $^{34}$

32 W.G. Zikmund, Business Research Methods (Ohio: Thomson-SouthWestern, 2003).

${ }^{33}$ E. Barbie \& J. Mouton, The Practice of Social Research (Cape Town: Oxford University Press, 2001).

34 L. R. Gay, G. E. Mills \& P. Airasian, Educational Research: Competencies for Analysis and Applications (Columbus: Merrill Greenwood, 2006), 489. 
Kaedah dan reka bentuk kajian yang dipilih ini akan menentukan hasil kajian kes dan analisis dokumen. Tempoh masa selama 3 tahun (2014-2016) telah diambil untuk memilih hanya responden yang memiliki karekter mak nyah sebagai responden. Sepanjang tempoh itu, penyelidik telah mengumpulkan seramai 253 orang responden transgender yang terdiri daripada mak nyah yang terlibat dengan kajian kuantitatif ini; dan melaksanakan kajian kualitatif melalui teknik temubual semi struktur bersama sembilan (9) orang, tetapi hanya tiga (3) orang mak nyah yang beragama Islam menjadi kajian kes untuk kajian kali ini.

Dapatan temubual membentuk tema-tema dan digabungkan dengan dapatan analisis dokumen untuk membentuk alat ukur. Penyelidik telah mendapatkan maklumat berkaitan transgender dan menemui mereka di Transsexual Drop-In Centre, Jalan Tunku Abdul Rahman, Kuala Lumpur. Responden iaitu mak nyah memberi nama, lokasi dan pekerjaan mereka. Premis tempat kerja mereka dikenal pasti seperti premis pengantin, kedai gunting rambut, kedai urut, sales girl dan kedai tukang jahit baju. Jadual 1 berikut memaparkan demografi responden:

Jadual 1: Demografi Responden

\begin{tabular}{|c|c|c|c|}
\hline Umur & Responden & $\begin{array}{c}\text { Peratusan } \\
(\%)\end{array}$ & Jumlah \\
\hline 21 hingga 29 tahun & 115 & 45 & \multirow[b]{4}{*}{$\begin{array}{c}253 \\
(100 \%)\end{array}$} \\
\hline 30 hingga 39 tahun & 99 & 39 & \\
\hline 40 hingga 49 tahun & 30 & 12 & \\
\hline $\begin{array}{l}\text { Bawah } 20 \text { tahun dan } \\
50 \text { tahun ke atas }\end{array}$ & 9 & 4 & \\
\hline Kumpulan Etnik & Responden & $\begin{array}{c}\text { Peratusan } \\
(\%)\end{array}$ & \multirow{5}{*}{$\begin{array}{c}253 \\
(100 \%)\end{array}$} \\
\hline Melayu & 170 & 67 & \\
\hline Cina & 31 & 12 & \\
\hline India & 0 & 0 & \\
\hline Lain-lain & 52 & 21 & \\
\hline
\end{tabular}


Zuraidah, Che Zarrina \& Chang "Transgenderisme di Malaysia: Pelan

Bimbingan Kembali Kepada Fitrah,” Afkār Vol. 20 Issue 2 (2018): 279-322

\begin{tabular}{|c|c|c|c|}
\hline Agama & Responden & $\begin{array}{c}\text { Peratusan } \\
(\boldsymbol{\%})\end{array}$ & \\
\hline Islam & 181 & 72 & \\
Kristian & 31 & 12 & \multirow{2}{*}{253} \\
Buddha & 17 & 7 & $(100 \%)$ \\
\hline Lain-lain & 24 & 9 & $(10 \%)$ \\
\hline
\end{tabular}

Sumber: Kajian lapangan 2014-2016

Majoriti 45\% ( $\mathrm{n}=115)$ orang responden berumur dari 21 sehingga 29 tahun, dan seramai 39\% (n=99) orang responden yang berumur 30 sehingga 39 tahun. Manakala $12 \%(n=30)$ orang responden pula berumur 40 sehingga 49 tahun, dan yang paling sedikit iaitu $4 \% \quad(n=9)$ orang responden yang berumur 50 tahun ke atas dan juga bawah 20 tahun. Kajian ini menunjukkan penglibatan secara aktif orang muda lebih ketara dalam isu transgender berbanding yang sudah berusia.

Dari sudut bangsa pula, didapati responden terdiri daripada pelbagai golongan etnik iaitu 67\% $(\mathrm{n}=170)$ adalah Melayu, $12 \%(n=31)$ adalah Cina, manakala 21\% $(n=52)$ adalah lain-lain etnik dan tiada responden daripada etnik India. Justeru, dapat dilihat bahawa golongan transgender ini lebih ramai dari kalangan etnik Melayu berbanding etnik lain yang berkemungkinan disebabkan kawasan tumpuan kajian adalah tempat kumpulan Melayu berkumpul. Namun faktor-faktor lain terjadinya demikian perlu dibuat kajian lanjut.

Sesuai dengan kepelbagaian etnik di Malaysia, hasil kajian turut meneliti aspek anutan agama. Justeru, kajian mendapati majoriti responden beragama Islam iaitu seramai $72 \%(n=181)$ orang, Kristian adalah seramai $12 \%(n=31)$ orang, Buddha pula adalah seramai $7 \%(n=17)$ orang, manakala lain-lain agama adalah seramai $9 \%(n=24)$ orang. Tiada responden yang beragama Hindu. Hasil dapatan ini juga adalah hampir selaras dengan dapatan etnik yang terlibat di mana golongan transgender berbangsa Melayu lebih ramai yang menunjukkan laras yang sama dengan 
agama anutan mereka. Lebihan responden yang beragama Islam sebanyai 11 orang berbanding etnik Melayu berkemungkinan disebabkan oleh adanya etnik lain yang menganut agama Islam.

\section{Tahap Komuniti Transgender Diterima Sebagai Sebahagian Daripada Masyarakat Di Malaysia}

Kajian yang dilakukan terhadap golongan mak nyah ini menunjukkan hanya $30 \% \quad(n=76)$ orang responden merasakan bahawa anggota komuniti transgender adalah diterima sebagai sebahagian daripada masyarakat di Malaysia, manakala majoriti responden iaitu seramai $70 \%$ $(n=177)$ merasakan masyarakat tidak dapat menerima mereka. Responden beranggapan masyarakat Malaysia termasuk ahli keluarga mereka menolak kehadiran mereka sebagai mak nyah disebabkan fahaman agama yang dianuti umum yang mewakili agama-agama seperti Islam dan Kristian yang melarang transgenderisme.

Menurut Wei et.al, ${ }^{35}$ salah satu faktor yang menyebabkan berlakunya percanggahan adalah disebabkan pemikiran atau norma dominan sesuatu masyarakat terhadap sistem sempadan gender. Idealnya, masyarakat beranggapan hanya terdapat dua jenis gender iaitu lelaki atau wanita. Peranan gender ditentukan berdasarkan genital yang dimiliki seseorang yang menyebabkan setiap individu diklasifikasikan sebagai ahli kepada gender/genital berkenaan dan bukan kepada yang lain. Individu yang tidak dapat mengidentifikasikan dirinya dalam mana-mana kelompok genital tersebut dianggap sebagai mengalami kecelaruan sistem gender. Oleh yang demikian, individu itu dianggap sebagai bermasalah.

Namun, kajian juga mendapati adanya tahap penerimaan yang baik dari ahli keluarga yang memberi sokongan kepada responden yang mempunyai identiti gender yang berbeza daripada identiti asal mereka. Minoriti

${ }^{35}$ Chang Lee Wei, et al., "Transgenderism in Malaysia", 95. 
responden berpendapat ahli-ahli keluarga mereka dapat menerima diri mereka, walaupun pada umumnya masyarakat di negara ini menyedari tingkah laku ini adalah bertentangan dengan norma sebenar. Hal ini boleh dilihat berlaku kepada Kamaliah (bukan nama sebenar) yang dibesarkan oleh keluarga ibunya. Kamaliah mula berasa dan berfikir seperti seorang wanita ketika dia berusia 7 tahun lagi. Dia pernah memakai pakaian wanita dan juga memakai kasut tumit tinggi ibunya semasa usia kanakkanak lagi. Dia tidak pernah dipaksa untuk memakai pakaian wanita dan ibunya juga tidak pernah marah ketika dia memakai pakaian wanita. ${ }^{36}$

Terdapat juga pandangan iaitu 25\% $(n=63)$ responden yang mengatakan masyarakat Malaysia dilihat menerima komuniti transgender kerana mereka perlu disantuni sebagai seorang manusia. Malah terdapat juga responden iaitu sebanyak $18 \% \quad(n=45)$ yang mengatakan bahawa golongan transgender atau transeksual mempunyai hak untuk memilih menjadi diri mereka sendiri iaitu mak nyah. Berdasarkan dapatan kajian ini, kebanyakan golongan mak nyah dapat menerima keadaan diri dan selesa menjadi golongan transgender. Penerimaan diri mereka sebagai transgender adalah pengiktirafan diri mereka sebagai individu yang mempunyai identiti, ekspresi dan tingkahlaku gender yang berbeza daripada individu normal. Ini bermakna mereka menganggap diri dan jantina mereka berbeza dengan jantina kelahiran asal mereka.

Kasih (bukan nama sebenar) sangat berharap agar masyarakat Malaysia memahami konsep gender dan seksualiti serta menerima golongan transgender sebagai

36 Temubual dengan Kamaliah (bukan nama sebenar) di Transsexual Drop-In Centre di Jalan Tunku Abdul Rahman, Kuala Lumpur, pada 3hb Mac 2015. 
sebahagian daripada masyarakat Malaysia. ${ }^{37}$ Manakala menurut Kamaliah, masyarakat Malaysia masih belum bersedia menerima mereka. Pada tanggapannya, pemahaman mengenai komuniti transgender dalam kalangan orang ramai masih sangat rendah. ${ }^{38}$

Penerimaan dan pengiktirafan diri mereka sebagai transgendermenyebabkan golongan ini mempunyai harapan untuk bebas membuat sebarang keputusan terutamanya apabila melibatkan status sosial. Ini termasuklah memilih menjadi jantina yang berbeza dengan jantina asal kelahiran mereka yang dalam konteks ini amat berkaitan dengan pengiktirafan mereka sebagai seorang perempuan dan bukannya lelaki, penampilan yang bebas, mendapatkan pekerjaan yang sesuai, mempunyai pasangan, berkahwin, memenuhi kehendak seksual di samping meminimum diskriminasi dan penyisihan yang berlaku.

Namun, kebanyakan golongan mak nyah berakhir dalam pencarian kerjayanya sebagai pekerja seks. Ini diakui sendiri oleh Kasih dan Kamaliah. Kasih menjelaskan bahawa dia pernah bekerja di luar negara sebagai pekerja seks. ${ }^{39}$ Kamaliah pula mengakui pernah bekerja sebagai penyambut tetamu, jurujual, mak andam dan pekerja seks. Malah dia turut mengatakan ramai mak nyah terpaksa bekerja di lorong-lorong yang memperdagangkan diri mereka sebagai hamba seks untuk mencari nafkah. Pengalamannya menjadi pekerja seks ini tidak menyenangkan, tetapi dia melakukannya untuk

37 Temubual dengan Kasih (bukan nama sebenar) di Transsexual DropIn Centre di Jalan Tunku Abdul Rahman, Kuala Lumpur, pada 26hb Februari 2015.

38 Temubual dengan Kamaliah (bukan nama sebenar) di Transsexual Drop-In Centre di Jalan Tunku Abdul Rahman, Kuala Lumpur, pada 3hb Mac 2015.

39 Temubual dengan Kasih (bukan nama sebenar) di Transsexual DropIn Centre di Jalan Tunku Abdul Rahman, Kuala Lumpur, pada 26hb Februari 2015. 
meneruskan kehidupannya di bandaraya Kuala Lumpur. ${ }^{40}$ Walau bagaimanapun, terdapat dalam kalangan mak nyah ini yang mempunyai pekerjaan yang baik seperti Sarah (bukan nama sebenar) yang merupakan seorang guru lulusan universiti tempatan berumur 37 tahun. $^{41}$

Sehingga kini, tiada satu peruntukan pun di dalam undang-undang yang mentakrifkan "lelaki" dan "perempuan. Akta Tafsiran 1967, Seksyen 4(2) hanya menyatakan "Mana-mana perkataan dan perbahasan yang ditujukan kepada kaum lelaki termasuklah perempuan". Walaubagaimanapun, perkataan yang ditujukan khusus kepada perempuan tidaklah pula termasuk dan meliputi lelaki. Kebanyakan undang-undang di Malaysia membezakan antara lelaki dan perempuan berdasarkan kepada butir-butir peribadi yang tercatat dalam surat beranak atau kad pengenalan. Sebarang pertukaran nama pada kad pengenalan adalah dibolehkan, namun apabila ia melibatkan pertukaran status jantina atau agama, maka ia akan melibatkan soal bidang kuasa perundangan yang perlu diputuskan oleh mahkamah.

Namun begitu, walaupun mereka dapat menerima diri mereka sebagai mak nyah, tetapi mereka masih menganggap masyarakat masih lagi belum bersedia dan tidak dapat menerima mereka sebagai salah satu kelompok dalam masyarakat. Hal ini dapat dilihat pada penceritaan Kasih yang sangat berharap dia dilahirkan sebagai perempuan. Walaupun dia adalah mak nyah, dia tidak berniat akan menjalani proses penukaran alat kelaminnya untuk menjadi wanita kerana memahami undang-undang di Malaysia menghalang mereka yang ingin menjalani

40 Temubual dengan Kamaliah (bukan nama sebenar) di Transsexual Drop-In Centre di Jalan Tunku Abdul Rahman, Kuala Lumpur, pada 3hb Mac 2015.

41 Temubual dengan Sarah (bukan nama sebenar) di Transsexual DropIn Centre di Jalan Tunku Abdul Rahman, Kuala Lumpur, pada 15hb Februari 2015. 
pembedahan perubahan alat kelamin. Baginya, tiada guna dia melakukan pembedahan jika dia tidak dapat memohon pertukaran kad pengenalan dan pasportnya kepada nama dan jantina baharunya. Dia faham bahawa kerajaan Malaysia sangat tegas dalam proses kad pengenalan atau pasport. Namun begitu, Kasih telah menjalani pembedahan implan payu dara di Bangkok dan mengambil hormon agar dia boleh meneruskan pekerjaan sambilannya sebagai pekerja seks. $^{42}$

Kajian ini juga mendapati $77 \%(n=196)$ responden mak nyah tidak diterima kerana aktiviti sosial mereka yang dikategorikan tidak bermoral terutama mak nyah yang bekerja sebagai pekerja seks. Ini merujuk kepada dua pegangan utama masyarakat Malaysia iaitu transgenderisme adalah bercanggah dengan prinsip agama dan hukum alam, dan transgenderisme menyebabkan nisbah jantina manusia menjadi tidak seimbang dari perspektif sains pembiakan. Berkenaan hal ini, Sarah yang telah insaf dan kembali ke fitrah asalnya sebagai lelaki meluahkan pengalaman pahitnya didera secara fizikal dan mental oleh pasangannya iaitu seorang lelaki membuatkan bekas mak nyah ini mula sedar akan kesilapan jalan yang dipilih selama ini.

Sarah ketika itu tidak dapat lagi menanggung penderitaan kehidupannya didera oleh pasangan lelakinya dan akhirnya mengambil keputusan untuk kembali menjalani kehidupan normal. Ketika mengalami trauma tersebut, Sarah sangat bersyukur kerana keluarganya telah menjadi tulang belakang untuk dia bangkit kembali ke pangkal jalan. ${ }^{43}$ Kamaliah pula menceritakan bagaimana

\footnotetext{
${ }^{42}$ Temubual dengan Kasih (bukan nama sebenar) di Transsexual DropIn Centre di Jalan Tunku Abdul Rahman, Kuala Lumpur, pada 26hb Februari 2015.

43 Temubual dengan Sarah (bukan nama sebenar) di Transsexual DropIn Centre di Jalan Tunku Abdul Rahman, Kuala Lumpur, pada 15hb Februari 2015.
} 
seorang rakannya yang bekerja sebagai pekerja seks di bilik sewaannya secara kejam dipukul sehingga mati. Rakannya ini juga setelah diautopsi oleh doktor perubatan disahkan dijangkiti HIV. Kamaliah akui dia melakukan kesalahan memilih jalan kehidupannya sebagai mak nyah dan dia kini cuba untuk balik ke pangkal jalan sebelum dia meninggal dunia dengan mengisi masanya untuk belajar agama dan bertaubat. $^{44}$

Namun, Kasih pula berlainan arah apabila berpendirian yang dia tetap akan mengubah dirinya sebagai lelaki dan bangga menjadi mak nyah. Kasih mengakui bahawa dia sedar perhubungan dengan pasangan kekasihnya tidak akan diterima oleh masyarakat dan agama. Namun dia menegaskan segala dosa yang dilakukannya biarlah antara dia dan Allah, bukannya masyarakat sekelilingnya yang menjadi tuhan. ${ }^{45}$

Justeru, daripada 253 responden yang mengambil bahagian dalam kajian ini, seramai 95\% $(n=240)$ bersetuju agar kerajaan dan masyarakat Malaysia perlu memberi perhatian kepada kebajikan komuniti transgender dari segi kesihatan terutama terhadap pencegahan jangkitan HIV/AIDS, diikuti dengan perundangan berkaitan dengan status, kesihatan dan peluang pekerjaan. Ini kerana sebahagian besar mak nyah yang menjadi responden kajian ini adalah pekerja seks, oleh itu pencegahan HIV/AIDS adalah sangat penting.

Sarah yang juga telah kembali ke fitrah asal kejadiannya sebagai lelaki sejati telah menekankan pentingnya menyeru golongan mak nyah mengenai penyakit HIV/AIDS, pencegahannya serta rawatannya. Dia

44 Temubual dengan Kamaliah (bukan nama sebenar) di Transsexual Drop-In Centre di Jalan Tunku Abdul Rahman, Kuala Lumpur, pada 3hb Mac 2015.

45 Temubual dengan Kasih (bukan nama sebenar) di Transsexual DropIn Centre di Jalan Tunku Abdul Rahman, Kuala Lumpur, pada 26hb Februari 2015. 
turut memberitahu adanya pertubuhan NGO di Malaysia yang memperjuangkan hak kemanusiaan menerima bantuan kewangan daripada global fund bagi menangani dan membanteras HIV/AIDS, tetapi sebenarnya mereka cuba menerapkan anasir yang boleh memesongkan akidah dan memperalatkan golongan yang terlibat. Justeru, Sarah juga mengatakan mak nyah sebagai golongan minoriti, tetapi ia menjadi racun kepada masyarakat Malaysia yang perlu ditangani dengan bijaksana. ${ }^{46}$ Hal ini juga sangat disarankan dalam kajian-kajian yang dilakukan oleh pelbagai penyelidik kerana ia menjadi suatu fenomena yang membimbangkan dalam masyarakat. ${ }^{47}$

Kajian lepas menunjukkan bahawa dalam konteks spiritual dan kehidupan beragama, golongan transgender tidak terlepas daripada dorongan untuk merasai dan menjalani aktiviti-aktiviti yang mengarah kepada kehendak spiritual dan keagamaan ini. Sama ada mereka berpegang kepada sesuatu agama; Islam, Kristian, Yahudi, Buddha, Hindu dan sebagainya, atau paling tidak mempunyai nilai spiritual atau kerohanian. Kajian mendapati keinginan ini tidak tersekat hanya disebabkan kecelaruan gender yang dialami. Bagi sebahagian kes transgender, kepercayaan dan hubungan dengan tuhan tidak terputus, malah hubungan ini menjadi lebih kuat apabila mereka berada dalam tekanantekanan tertentu. ${ }^{48}$

46 Temubual dengan Sarah (bukan nama sebenar) di Transsexual DropIn Centre di Jalan Tunku Abdul Rahman, Kuala Lumpur, pada 15hb Februari 2015.

${ }^{47}$ Bockting, W.O., Rosser, B.R.S., \& Scheltema, K., "Transgender HIV Prevention: Implementation and Evaluation of A Workshop," Health Education Research 14(2) (1999), 177-183; Bockting, W. O., Robinson, B. E., \& Rosser, B. R., "Transgender HIV Prevention: A Qualitative Needs Assessment," AIDS Care 10 (1998), 505-525.

${ }^{48}$ Minwalla O, Rosser BR, Feldman J, Varga C., Identity Experience Among Progressive Gay Muslims in North America: A Qualitative Study Within Al-Fatiha Cult Health Sex, 2005 Mar;7(2):113-128. 
Dalam kajian lain, responden menyatakan bahawa mereka mengunjungi tempat-tempat ibadat dan melakukan ibadat seperti individu lain. Kunjungan ke tempat-tempat ibadat seperti gereja, kuil dan juga masjid serta perbincangan dengan rakan-rakan yang memahami keadaan diri mereka dapat memberi ketenangan dan kesejahteraan dalam diri, walaupun terdapat konflik di antara identiti gender dan identiti agama yang dipegang transgender. ${ }^{49}$ Dalam konteks Malaysia, didapati ramai di kalangan transgender Muslim yang masih berpegang kepada akidah Islam walaupun tidak dapat dikenalpasti sama ada golongan ini menjalankan ibadah-ibadah yang dituntut dalam Islam atau tidak. ${ }^{50}$

\section{Pelan Bimbingan Golongan Transgender}

Bagi menghadapi cabaran transgender dalam masyarakat, pelbagai usaha telah digembeling oleh pihak kerajaan khususnya JAKIM, majlis dan jabatan agama negeri, NGO dan individu. Kajian-kajian akademik juga telah banyak dilakukan. Kajian ini turut merangka pelan bimbingan terhadap golongan transgender mendasari perspektif psikospiritual Islam di samping hal-hal berkaitan yang memberi penekanan merangkumi beberapa perkara utama sebagaimana berikut:

\section{Intervensi Psikospiritual Islam}

Psikospiritual Islam merupakan suatu ilmu tentang konsep dan praktis pengabdian dan penyerahan diri kepada Allah SWT yang selaras dengan fitrah asal manusia. ${ }^{51}$ Ia

49 D. I. García, J. Gray-Stanley \& J. Ramirez-Valles, "The priest Obviously Doesn't Know That I'm Gay: The Religious and Spiritual Journeys of Latino Gay Men," Journal of Homosexuality, Bil. 55(3) (2008), 411-436.

50 Teh, Y.K., "Mak Nyahs (Male Transsexuals in Malaysia): The influence of Religion and Culture on Their Identity," International Journal of Transgenderism, Bil. 5(3) (2001), 1-13.

51 Mohd Shahril Othman, Psikospiritual Islam (Terengganu: Penerbit Universiti Sultan Zainal Abidin, 2014), 11. 
menggagaskan suatu metode rawatan bagi penyakit kejiwaan atau rohani berdasarkan ajaran Islam sehingga mampu mewujudkan kestabilan diri, jiwa dan roh. Psikologi spiritual Islam atau psikospiritual Islam yang membahaskan tentang psikologi insan ini dicetuskan melalui disipilin ilmu tasawuf yang merupakan sunnah Rasulullah SAW, sahabat dan ahli sufi. ${ }^{52}$ Justeru, pendekatan psikospiritual Islam ini sangat bersesuaian untuk diterapkan dalam membimbing dan mengajak golongan transgender kembali kepada fitrah.

Menurut Hasimah, Che Zarrina dan Loh, ${ }^{53}$ elemenelemen dalam perbincangan psikospiritual Islam menunjukkan kesatuan seluruh aspek dalaman diri seseorang dalam usaha merasai, mendalami dan menghayati kerohanian dalam ajaran agama. Idea dan praktikal al-Ghazali menekankan bimbingan terhadap empat aspek utama spiritual iaitu ‘aql (akal), nafs (jiwa/nafsu), qalb (hati/jantung) dan rūh (roh) mempunyai tiga proses utama iaitu pembersihan jiwa (tazkiyah al-nafs), berjihad melawan nafsu (mujāhadah al-nafs) dan latihan jiwa (riyādah al-nafs). ${ }^{54}$ Proses ini pula sangat berkait dengan proses pengosongan diri dari perbuatan keji (takhalli) yang juga menyamai proses tazkiyah al-nafs dan pengisian jiwa dengan ibadah dan amal soleh (tahalli) yang menyerupai riyādah al-nafs. Manakala proses mujāhadah al-nafs yang bermaksud berusaha melawan dan menahan diri dari sesuatu yang negatif pula berlaku di sepanjang kedua-dua proses tersebut.

52 Che Zarrina binti Sa'ari dan Joni Tamkin bin Borhan, "Psikospiritual dan Metodologi Pengaplikasiannya dalam Kehidupan," dalam Koleksi Kertas Kerja Isu Semasa: Menghurai Permasalahan Islam Semasa (Putrajaya: JAKIM, 2006), 63.

${ }^{53}$ Hasimah Chik, Che Zarrina Sa'ari \& Loh Ee Chin, "Peranan Spiritual dalam Rawatan Paliatif," Journal of Afkar, Bil. 19 (2) (2017),120-122.

${ }^{54}$ Sharifah Basirah Syed Muhsin \& Che Zarrina Sa'ari. "Beberapa Aspek Psikoterapi Islam dalam Kitab Jawi, 'Penawar Bagi Hati' oleh Sheikh Abdul Qadir al-Mandili.” Journal of Afkar, Bil.14, (2013), 135-137. 
Dalam konteks transgender, proses tazkiyah al-nafs, riyādah al-nafs dan mujāhadah al-nafs melibatkan suatu usaha yang bersungguh-sungguh untuk membersihkan dan menyucikan jiwa daripada sifat yang tercela iaitu menurut hawa nafsu menjalani corak kehidupan terlarang dari nilai agama dan norma masyarakat. Ia merupakan satu proses peralihan dari jiwa yang kotor, ternoda dan tercemar dengan dosa kepada jiwa yang bersih. Proses utama mesti dilalui dengan bantuan psikoterapis syarie yang perlu mahir dalam menjelaskan keseluruhan terapi yang dicadangkan dengan menghubungkaitkannya dengan Terapi Iman (sekurang-kurangnya Terapi Tauhidik, Terapi Ukhrawi, Terapi Taqdiri), Terapi Islam (sekurang-kurangnya Terapi Solat, Terapi Puasa, Terapi Sedekah) dan Terapi Ihsan (penghayatan bahawa manusia melihat Allah atau sekurang-kurangnya manusia melihat Allah). Proses utama tersebut ialah:

Jadual 2: Intervensi Psikopsiritual Islam

\begin{tabular}{|c|c|c|c|}
\hline Terapi & Langkah & Kaedah & Pendetailan \\
\hline $\begin{array}{l}\text { Mengenali } \\
\text { kelemahan dan } \\
\text { kekuatan diri }\end{array}$ & $\begin{array}{l}\text { Meneliti diri } \\
\text { (muhāasabah } \\
\text { al-nafs) }\end{array}$ & $\begin{array}{l}\text { i. Apakah faktor } \\
\text { keterlibatan } \\
\text { dalam kancah } \\
\text { transgender } \\
\text { ii. Apakah pula } \\
\text { kekuatan diri } \\
\text { yang boleh } \\
\text { membantu ke } \\
\text { arah } \\
\text { perubahan }\end{array}$ & $\begin{array}{l}\text { i. Berbincang } \\
\text { dengan } \\
\text { psikoterapis/ } \\
\text { ii. individu yang } \\
\text { hampir } \\
\text { iii. Merenung diri }\end{array}$ \\
\hline $\begin{array}{l}\text { Melaksanakan } \\
\text { proses taubat }\end{array}$ & $\begin{array}{l}\text { Memohon } \\
\text { keampunan } \\
\text { kepada Allah } \\
\text { sebagai } \\
\text { Pencipta, } \\
\text { kemaafan } \\
\text { kepada kedua } \\
\text { ibubapa dan } \\
\text { keluarga serta }\end{array}$ & 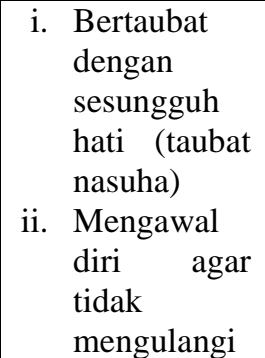 & $\begin{aligned} & \text { i. } \text { Memperbaikkan } \\
& \text { solat fardhu } \\
& \text { ii. Memperbanyak } \\
& \text { an solat sunat } \\
& \text { iii. Mengaji dan } \\
& \text { mentadabbur al- } \\
& \text { Qur'an } \\
& \text { iv. Memperbanyak } \\
& \text { an berzikir }\end{aligned}$ \\
\hline
\end{tabular}


Zuraidah, Che Zarrina \& Chang "Transgenderisme di Malaysia: Pelan

Bimbingan Kembali Kepada Fitrah,” Afkār Vol. 20 Issue 2 (2018): 279-322

\begin{tabular}{|c|c|c|c|}
\hline & $\begin{array}{l}\text { memaafi diri } \\
\text { sendiri. }\end{array}$ & 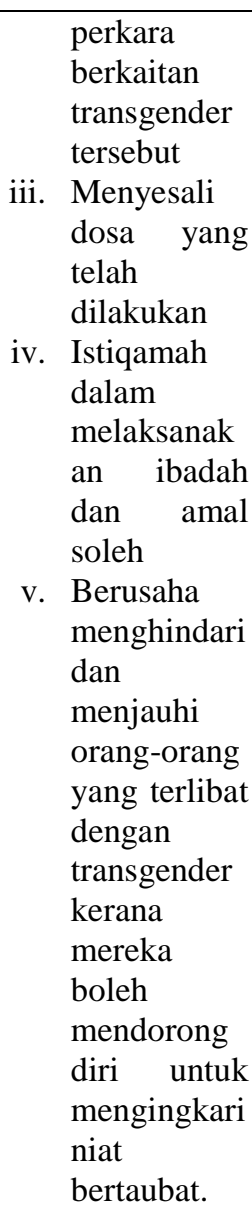 & 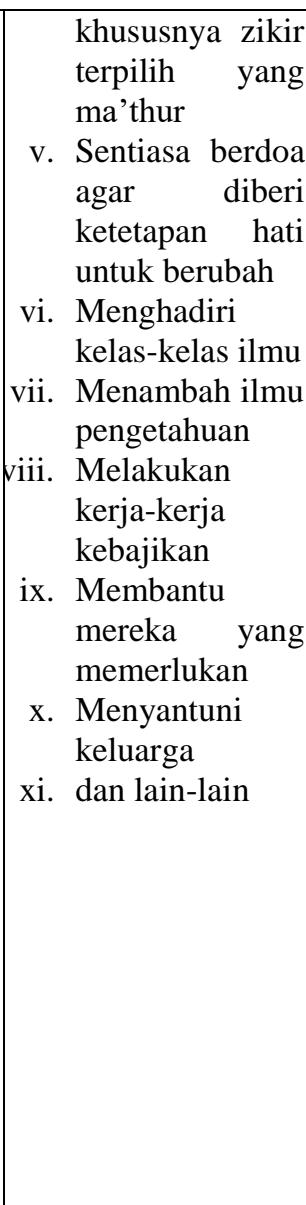 \\
\hline $\begin{array}{l}\text { Menanam dan } \\
\text { mengaplikasi } \\
\text { sifat sabar }\end{array}$ & $\begin{array}{l}\text { Melatih diri } \\
\text { dengan penuh } \\
\text { kesabaran } \\
\text { dalam } \\
\text { berusaha } \\
\text { membuang } \\
\text { sifat suka } \\
\text { menuruti hawa } \\
\text { nafsu, godaan } \\
\text { syaitan dan }\end{array}$ & $\begin{array}{l}\text { Kesabaran dapat } \\
\text { dipupuk dengan } \\
\text { sentiasa } \\
\text { memotivasi diri } \\
\text { beribadah dan } \\
\text { beramal soleh. }\end{array}$ & $\begin{aligned} & \text { i. } \begin{array}{l}\text { Melaksanakan } \\
\text { semua perkara } \\
\text { di atas }\end{array} \\
& \text { ii. } \begin{array}{l}\text { Menjauhkan } \\
\text { diri daripada }\end{array} \\
& \text { rakan } \\
& \text { transgender } \\
& \text { iii. } \begin{array}{l}\text { Berhenti } \\
\text { melayari laman } \\
\text { sesawang }\end{array}\end{aligned}$ \\
\hline
\end{tabular}


Zuraidah, Che Zarrina \& Chang "Transgenderisme di Malaysia: Pelan

Bimbingan Kembali Kepada Fitrah,” Afkār Vol. 20 Issue 2 (2018): 279-322

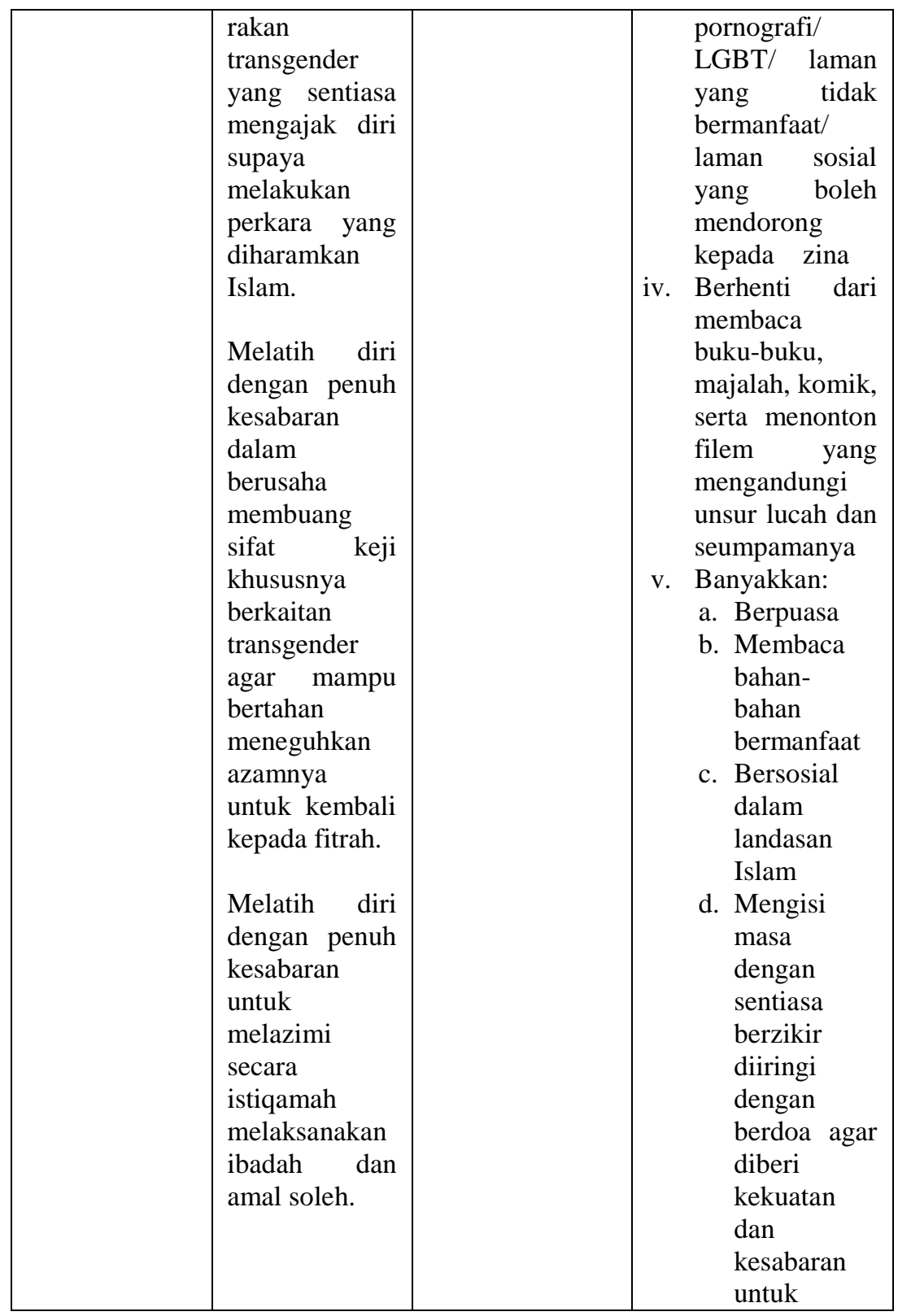




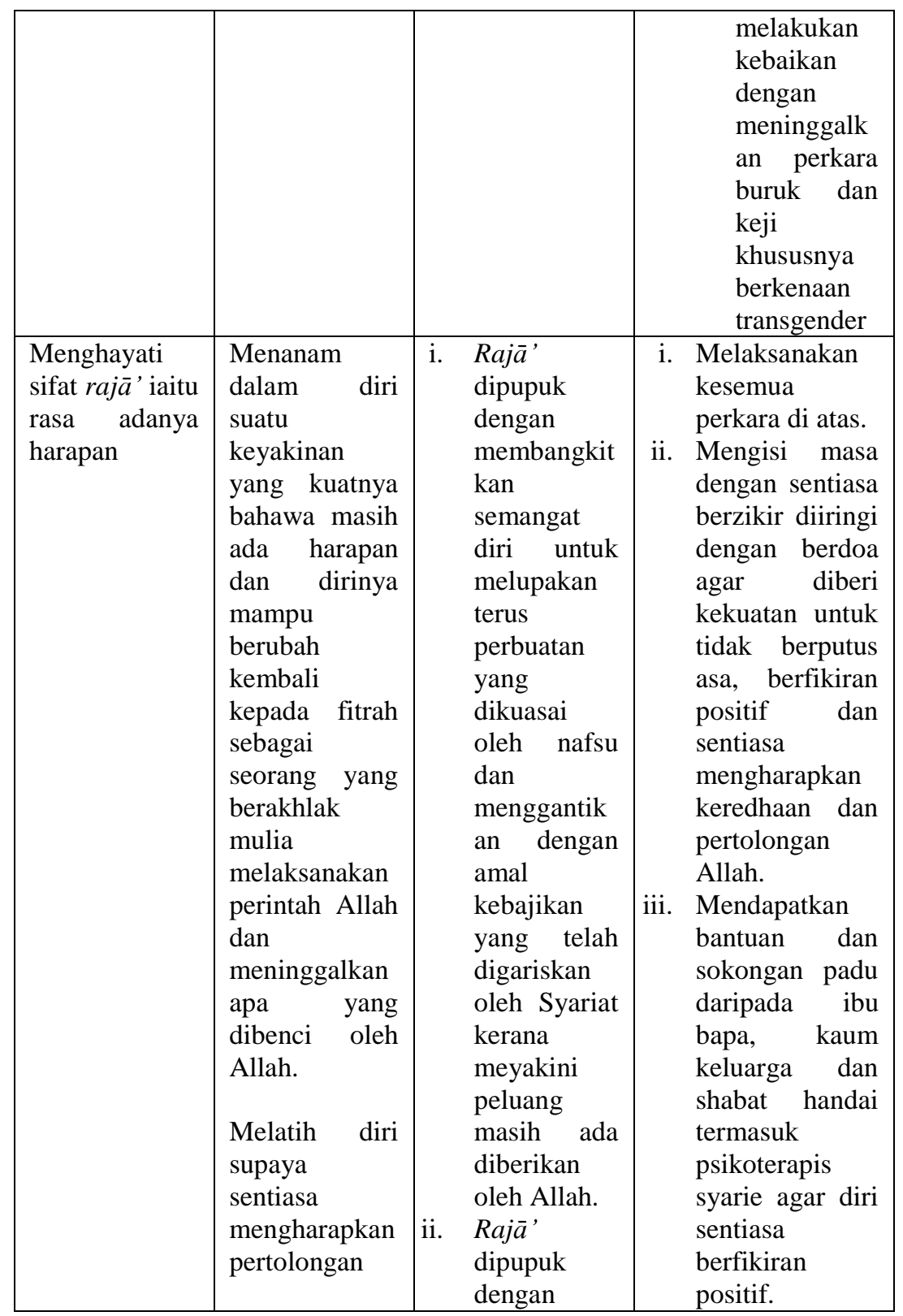


Zuraidah, Che Zarrina \& Chang "Transgenderisme di Malaysia: Pelan

Bimbingan Kembali Kepada Fitrah,” Afkār Vol. 20 Issue 2 (2018): 279-322

\begin{tabular}{|c|c|c|c|}
\hline & $\begin{array}{l}\text { daripada } \\
\text { Allah. } \\
\text { Melatih diri } \\
\text { agar diri } \\
\text { bergantung } \\
\text { hidup secara } \\
\text { mutlak kepada } \\
\text { Allah kerana } \\
\text { Allah adalah } \\
\text { Tuhan dan diri } \\
\text { hanyalah } \\
\text { makhlukNya. }\end{array}$ & \begin{tabular}{|l} 
keyakinan \\
bahawa \\
Allah \\
bersifat \\
Maha \\
Penyayang \\
dan Maha \\
Pengampun. \\
iii. \\
Rajä \\
dipupuk \\
dengan \\
meyakini \\
kekuasaan \\
Allah yang \\
menyebabka \\
n semakin \\
kuat \\
pergantunga \\
n hidupnya \\
kepada \\
Allah.
\end{tabular} & \\
\hline $\begin{array}{l}\text { Menghayati } \\
\text { sifat khawf } \\
\text { iaitu rasa takut }\end{array}$ & $\begin{array}{l}\text { Melatih diri } \\
\text { untuk } \\
\text { menghayati } \\
\text { rasa takut } \\
\text { kepada } \\
\text { Pencipta yang } \\
\text { Maha } \\
\text { Berkuasa. }\end{array}$ & $\begin{array}{l}\text { Memupuk sifat } \\
\text { khawf atau rasa } \\
\text { takut bahawa: } \\
\text { i. Lenyap dan } \\
\text { hilangnya } \\
\text { iman di } \\
\text { dada. } \\
\text { ii. } \text { Manusia } \\
\text { tidak } \\
\text { berkuasa } \\
\text { tetapi Allah } \\
\text { Maha } \\
\text { Berkuasa } \\
\text { dan Maha } \\
\text { Penghukum. } \\
\text { iii. Hidup } \\
\text { manusia } \\
\text { akan } \\
\text { berakhir }\end{array}$ & $\begin{aligned} & \text { i. } \text { Melaksanakan } \\
& \text { kesemua } \\
& \text { perkara di atas. } \\
& \text { ii. }\end{aligned}$ \\
\hline
\end{tabular}




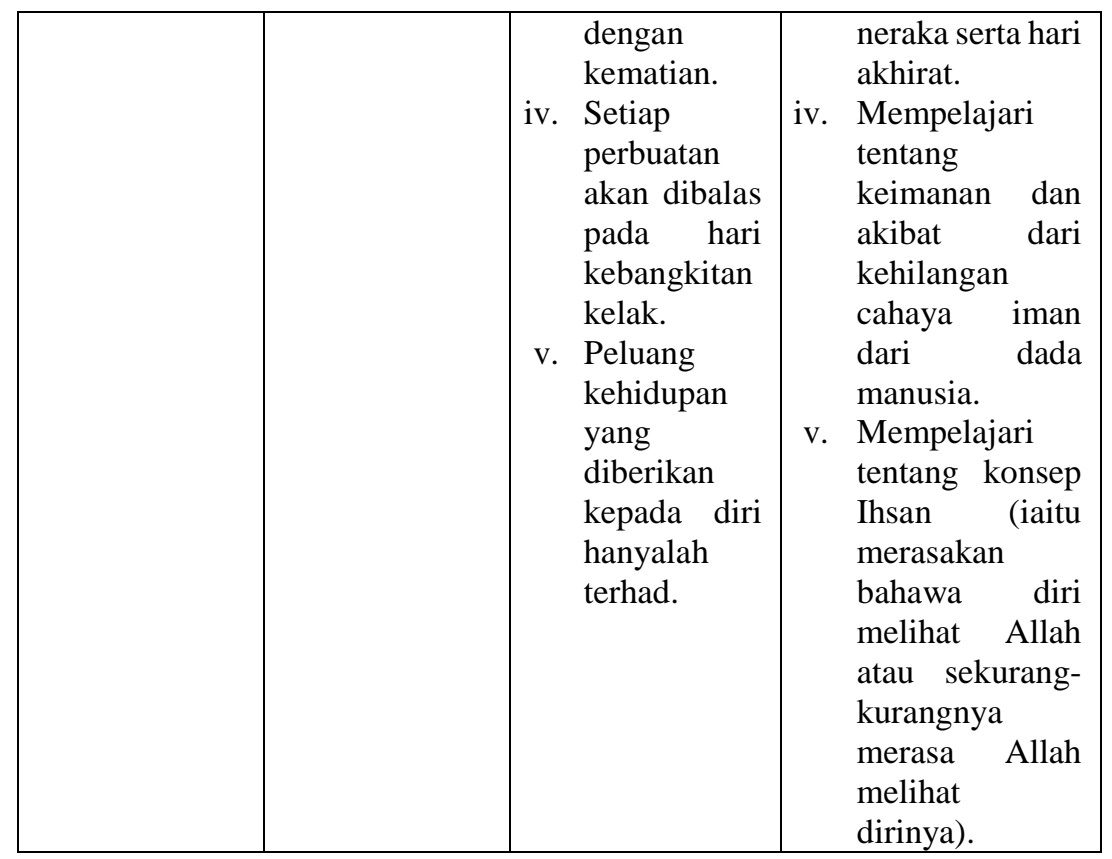

Sumber: Abū Ṭālib al-Makkī, Qūt al-Qulū $b^{.55}$

Selain itu, program-program di bawah juga boleh dijalankan dengan menerapkan nilai-nilai psikospiritual Islam dalam pelaksanaannya, antaranya:

2. Bimbingan kaunseling syarie oleh kaunselor syarie Kaedah bimbingan kaunseling syarie sangat penting bagi membuka peluang kepada golongan transgender berkongsi rasa dan pengalaman hidup agar dapat dibimbing untuk mengenal potensi diri sebagai khlaifah Allah serta mampu

55 Abū Țālib al-Makkī, Qūt al-Qulūb (Beirut: Dār al-Kitāb al'Ilmiyyah, 1997); Che Zarrina Sa'ari \& Sharifah Basirah Syed Muhsin, "Cadangan Model Psikoterapi Remaja Islam Berasaskan Konsep Tazkiyah al-Nafs," Jurnal Usuluddin, Bil. 36 (Julai-Disember 2012), 49-74; 'Abd al-Qādir al-Mandīlī, Penawar bagi Hati (Pattani: Sahabat Press, 1964); Abū al-Qāsim 'Abd al-Karīm al-Qushayrī, alRisālah al-Qushayriyyah, ed. 'Abd al-Ḥalīm Mạ̣mūd (Kaherah: Dār al-Khayr, 2003). 
mebuat keputusan atau menyelesaikan masalah yang dihadapi berasaskan syraiat Islam. Justeru, golongan ini mempunyai tempat tuju bagi membantu mereka kembali kepada fitrah. Intipati kauseling syarie ini boleh dirujuk kepada Manual Kaunseling Syari'e $e^{56}$ dan khidmat kaunseling syarie ini boleh didapati secara percuma di KSKCare Centre, Masjid Tuanku Mizan Zainal Abidin Putrajaya. $^{57}$

\section{Kesedaran undang-undang}

Golongan transgender ini juga perlu diberi pendedahan dan kesedaran mengenai penentuan dan pelaksanaan hukum Syariah yang dilaksanakan di Malaysia. Mereka bukan hanya didedahkan dengan hukuman tersebut, tetapi perlu dijelaskan secara mendetail hikmah di sebalik penetapan dan pelaksanaan hukuman tersebut. Penjelasan pula perlu dikaitkan dengan penghayatan keimanan kepada Allah SWT yang Maha Penyayang (al-Rahim) dan Maha Pengampun (al-Ghaffār) yang pada masa yang sama adalah Maha Menghukum (al-Hakam) dan Maha Penyiksa (alMuntaqim). ${ }^{58}$

Kemahiran terhadap intipati modul intervensi Psikospiritual Islam akan membantu psikoterapis syarie dan pendakwah. Pada sesi ini mereka juga perlu didedahkan mengenai Kesalahan Jenayah Syariah Negeri-Negeri yang melibatkan peruntukan kesalahan sebagaimana berikut: ${ }^{59}$

56 Abdul Ghaffar Surip et. al., Manual KaunselingSyari'e (Putrajaya: Jabatan Kemajuan Islam Malaysia (JAKIM), 2013), 8

57 Temubual dengan Ustazah Rosliza Abdul Latif, JAKIM pada 20hb September 2018.

58 Abū Hāmid al-Ghazālī, al-Maqșad al-Asnā fī Sharh Asmā' Allāh alHusnā, tahqiq. Abū Sahl \& Najāḥ Iwāḍ Șiyām (Kaherah: Dār alMuqțim, 2008); Mohd Hasrul Mohd Shuhari \& Mohd Fauzi Hamad, "Al-Maqsad al-Asna Sebagai Sebuah karya Akidah al-Ghazali," Journal of Afkar, Bil. 15 (2014), 1-44.

59 Mahfudzah Mohamad, "Lesbian, Gay, Biseksual dan Transgender: Perspektif Undang-undang Jenayah Syariah," Jurnal Undang-undang dan Masyarakat, Bil. 19 (2015), 33. 
i. Liwat, apabila disabitkan boleh didenda tidak melebihi RM5,000.00 atau dipenjarakan selama tempoh tidak melebihi tiga tahun atau disebat tidak melebihi enam sebatan atau dihukum dengan mana-mana kombinasi hukuman itu (Seksyen 25 AKJSWP 1997).

ii. Musahaqah iaitu merujuk kepada mana-mana orang perempuan yang melakukan musahaqah apabila disabitkan boleh didenda tidak melebihi RM5,000.00 atau dipenjarakan selama tempoh tidak melebihi tiga tahun atau disebat tidak melebihi enam sebatan atau dihukum dengan mana-mana kombinasi hukuman itu (Seksyen 26 AKJSWP 1997).

iii. Pondan (Seksyen 7 Enakmen Kanun Jenayah Syariah (Negeri Kelantan) 1985). Lelaki berlagak seperti perempuan yang merujuk kepada manamana orang lelaki yang memakai pakaian perempuan dan berlagak seperti perempuan di mana-mana tempat awam atas tujuan tidak bermoral apabila disabitkan boleh didenda tidak melebihi satu ribu ringgit atau dipenjarakan selama tempoh tidak melebihi satu tahun atau keduaduanya. Selain hukuman tersebut, terdapat satu peruntukan undang-undang yang bersesuaian untuk mengawal selia jenayah tersebut sekiranya ciri dalam seksyen 28 tidak mencukupi untuk didakwa, iaitu perkara tidak sopan di tempat awam seksyen 29 Enakmen Kesalahan Jenayah Syariah Negeri Johor 1997. Peruntukan tersebut telah menyebut: Mana-mana orang yang bertindak atau berkelakuan tidak sopan bertentangan dengan hukum syarak di mana-mana tempat awam adalah melakukan suatu kesalahan dan apabila disabitkan boleh didenda tidak melebihi RM1000.00 ringgit atau dipenjarakan selama tempoh tidak melebihi 
enam bulan atau kedua-duanya. Peruntukan ini meskipun bersifat umum boleh menghukum sesiapa sahaja yang melakukan perbuatan tidak sopan di tempat awam kerana dalam peruntukan tersebut ada disebut perkataan, "bertindak atau berkelakuan tidak sopan", bermaksud perkataan tersebut seperti yang diterangkan dalam Arahan Amalan No. 8 Tahun 2005 seperti yang berikut: i) bercumbu-cumbuan; ii) berpeluk-pelukan; iii) pertuturan atau isyarat lucah atau berpakaian yang menghairahkan; atau lain-lain perbuatan yang tidak sopan yang bertentangan dengan hukum syarak. (Seksyen 28 AKJSWP 1997). Terdapat perbezaan nama kesalahan bagi sesetengah enakmen negeri antaranya ialah: Seksyen 92: Lelaki berlagak seperti perempuan atau sebaliknya, Enakmen Kesalahan Jenayah Syariah 1995 Negeri Sabah.

iv. Perempuan berlagak seperti lelaki (Seksyen 34 Enakmen Kesalahan Jenayah Syariah 2013 (Negeri Pahang)).

v. Perhubungan jenis luar tabi'e (Seksyen 58 Enakmen Kesalahan Syariah (Negeri Melaka) 1991). Terdapat juga kesalahan yang sama tetapi menggunakan nama kesalahan yang berlainan iaitu Seksyen 76: Persetubuhan Luar Tabii, Enakmen Kesalahan Jenayah Syariah 1995 (Negeri Sabah). Seksyen 65: Persetubuhan di luar tabii semula jadi, Enakmen Jenayah Syariah Negeri Sembilan 2004. Seksyen 28: Persetubuhan bertentangan dengan hukum tabii, Enakmen Jenayah Syariah (Selangor) 1995.

vi. Hubungan jenis antara orang yang sama jantina (Seksyen 27 Enakmen Jenayah Syariah (Selangor) 1995). 


\section{Program Outreach}

Golongan transgender mesti didekati dan bukan dijauhi. Justeru, mereka perlu disantuni dengan menghampiri dan mendekati mereka melalui contoh teladan yang baik selaras dengan kehendak akhlak Islam. Pendekatan street da'wah perlu disusun dan dilaksanakan secara lebih kerap dan berkala. Kemahiran terhadap intipati modul intervensi Psikospiritual Islam akan membantu psikoterapis syarie atau pendakwah mendekati mereka dengan penuh berhikmah. Antara strategi dakwah yang sesuai dilakukan terhadap mereka ialah: ${ }^{60}$

i. Pendekatan berhemah dan berlemah lembut dengan menggunakan kata-kata yang baik, memberi galakan dan nasihat serta pengajaran dengan intonasi yang sesuai, mengguna perkataan yang sesuai dengan situasi mereka supaya mudah difahami. Intipati modul intervensi psikospiritual Islam boleh digunapakai ketika ini.

ii. Pendekatan perdebatan atau perbahasan yang terbaik supaya golongan ini tidak mudah tersinggung atau menjauhkan diri. Malah akhlak mulia yang ditonjolkan mampu menarik minat mereka untuk mendekati ajaran Islam, malah membuka hati mereka untuk membincangkan halhal yang kurang difahami.

\section{Program Kem Ibadah}

Program ini sangat penting kerana ia mampu mengumpul dan melatih golongan transgender ini dalam jangka masa tertentu. Ia juga sangat bermanfaat apabila golongan transgender yang mengikuti program ini akan

${ }^{60}$ Khairul Hamimah Mohammad Jodi \& Noor Hafizah Mohd Haridi, "Cabaran dan Pendekatan Dakwah Golongan LGBT: Satu Kajian di Pertubuhan Usrah Fitrah," dalam Pembangunan Insan Kamil dalam Mendepani Era Milenia, eds. Nor Raudah Hj Siren et. al. (Kuala Lumpur: Akademi Pengajian Islam Universiti Malaya, 2018), 295298. 
mempunyai masa yang panjang berinteraksi dengan psikoterapis syarie atau pendakwah, malah mereka juga boleh bertukar pandangan sesama mereka. Modul intervensi Psikospiritual Islam boleh digunakan dalam program ini yang seharusnya dibuat secara berkala. Pihak Bahagian Keluarga, Sosial dan Komuniti dan juga Bahagian Dakwah JAKIM telahpun memulakan program ini. ${ }^{61}$

\section{Rumusan}

Golongan minoriti seksual adalah sekumpulan manusia yang dilihat pembahagiannya dari sudut pola atau orientasi seksual manusia. Ia bermula dengan perasaan dan naluri seks dan diterjemahkan dalam pelakuan seks itu sendiri. Apapun istilah yang diberikan kepada individu golongan minoriti ini ia sebenarnya berkait rapat dengan konflik identiti dan mengalami orientasi seks yang ganjil (alshudhüdh al-jinsiyyah). Kewujudan mereka tidak mungkin dapat dinafikan kerana desakan nafsu akan tetap wujud selagi terdapatnya kehidupan manusia.

Justeru, peranan semua pihak dalam mencari jalan penyelesaian sama ada dalam bentuk bimbingan atau penguatkuasaan perlu diperkasakan. Kajian terhadap golongan ini perlu bersifat berterusan dan dipergiatkan sama ada yang berkaitan perundangan, psikologi, sosial dan pendekatan keagamaan. Kesukaran untuk memahami mengapa berlakunya tarikan seksual selain heteroseksual adalah satu cabaran. Untuk mengurang, mengatasi, memulih, merawat mereka adalah juga suatu cabaran besar.

Pendekatan kaunseling dan bimbingan berteraskan Islam atau dengan input agama perlu diketengahkan dan diperluas dalam masyarakat sebagai usaha mendepani golongan minoriti seksual. Ini penting supaya Islam tidak disalah tafsirkan sebagai penghukum semata-mata tanpa

61 Memahami Lesbian, Gay, Bioseksual dan Transgender Dari Perspektif Seorang Muslim (Putrajaya: Jabatan Kemajuan Islam Malaysia (JAKIM) \& Yayasan Ihtimam Malaysia, t.th). 
menerima sifat toleran untuk berinteraksi sesama manusia. Di samping itu, membuktikan bahawa kaunseling Barat (tanpa berpandukan garis-garis tertentu) berbeza dengan kaunseling Islam yang meletakkan al-Qur'an dan sunnah sebagai panduannya.

\section{Rujukan}

Akta Kesalahan Jenayah Syariah (Wilayah Persekutuan) 1997 (Akta 559).

Akta Kesalahan Kecil 1955.

'Ali, 'Abdullah Yusuf. The Meaning of the Holy Qur'ān. Maryland: Amana Publication, 1997.

American Psychological Association, Answers to Your Questions About Transgender People, Gender Identity and Gender Expression. http://www.apa.org/topics/sexuality/transgender.pdf Arahan Amalan Mahkamah Syariah No. 8 Tahun 2005. Al-'Asqalāni, Aḥmad bin 'Alī bin Hajar. Fath al-Bārì bi Sharh Sahịh al-Imām Abì 'Abd Allāh Muhammad bin Ismā'ìl al-Bukhārì, tahqiq. 'Abd al-Qādir Shaybah alHamad. Saudi Arabia: Maktabah al-Malik Fahd alWațaniyyah, 2001.

Azizi Yahaya \& Jamaludin Ramli. Psikologi Abnormal. Skudai: Universiti Teknologi Malaysia, 2007.

Bahagian Agama Jabatan Perdana Menteri. Fatwa Pertukaran Jantina dari Lelaki kepada Perempuan dan Sebaliknya. 11 November 1982.

Barbie, E. \& Mouton, J. The Practice of Social Research.

Cape Town: Oxford University Press, 2001.

Al-Bayhāqī, Abū Bakr Aḥmad bin al-Ḥusayn. Shu'ab alImān, tahqiq. Muhammad al-Sa‘'̄id Basyūni Zaghlūl. Beirut: Dār al-Kutub al-'Alami, $1410 \mathrm{H}$.

Benjamin, H. The Transsexual Phenomenon; a Scientific Report on Transsexualism and Sex Conversion in the Human Male and Female. New York and London: The Julian Press Inc., 1996. 
Bockting, W. O., Robinson, B. E., \& Rosser, B. R., "Transgender HIV Prevention: A Qualitative Needs Assessment," AIDS Care 10, 1998: 505-525.

Bockting, W.O., Rosser, B.R.S., \& Scheltema, K., "Transgender HIV Prevention: Implementation and Evaluation of A Workshop," Health Education Research 14(2), 1999: 177-183.

Chang, L.W., Azizan, B., Raihanah, A., Zuraidah, A. \& Kathleen, P.C.E., "Transgenderism in Malaysia," Journal of Dharma 37(1), (January-March 2012): 79-96. Che Zarrina binti Sa'ari \& Joni Tamkin bin Borhan. "Psikospiritual dan metodologi Pengaplikasiannya dalam Kehidupan." Dalam Koleksi Kertas Kerja Isu Semasa: Menghurai Permasalahan Islam Semasa. Putrajaya: JAKIM, 2006.

Che Zarrina Sa'ari \& Sharifah Basirah Syed Muhsin. "Cadangan Model Psikoterapi Remaja Islam Berasaskan Konsep Tazkiyah al-Nafs." Jurnal Usuluddin Bil. 36 (Julai-Disember 2012): 49-74.

Che Zarrina Saari \& Mohd Manawi Mohd Akib, "Beberapa Persoalan Berkaitan Konsep Insan Menurut Fakhr al-Din al-Razi," Journal of Afkar Bil. 19 (Special Issue) 2017: 87-114.

Clarke, Victoria. "Resistance and Normalization in the Construction of Lesbian and Gay Families: A Discursive Analysis." In Lesbian and Gay Psychology: New Perspectives, eds. Adrian Coyle \& Celia Kitzinger. Oxford: BPS Blackwell, 2002: 98-116.

Dewan Redaksi. Ensiklopedi Islam. Jakarta: Ichtiar Baru Van Hoeve, 2001.

Enakmen Kesalahan Jenayah Syariah Negeri Johor 1997 (Enakmen No. 4 Tahun 1997).

García, D. I., Gray-Stanley, J., \& Ramirez-Valles, J., "The Priest Obviously Doesn't Know that I'm gay: The Religious and Spiritual Journeys of Latino Gay 
Men," Journal of Homosexuality, Bil. 55(3) (2008): 411436.

Garrett, J., Wilhelm, H. eds. The Bhagavat-Geeta or Dialogues of Krishna and Arjoon in Eighteen Lectures. Bangalore: Wesleyan Mission Press, 1849.

Gay, L. R., Mills, G. E., \& Airasian, P. Educational Research: Competencies for Analysis and Applications. Columbus: Merrill Greenwood, 2006.

Al-Ghazālì, Abū Hāmid. Al-Maqșad al-Asnā fī Sharh Asmā' Allāh al-Husnā, tahqiq. Abū Sahl \& Najāḥ Iwāọ Șiyām. Kaherah: Dār al-Muqtịm, 2008.

Hasimah Chik, Che Zarrina Sa'ari \& Loh Ee Chin. "Peranan Spiritual dalam Rawatan Paliatif," Journal of Afkar, Bil. 19(2) (2017): 107-142.

Al-Jurjāni, 'Alì Muhammad al-Sharif. Al-Ta 'rífāt. Beirut: Dār al-Kutub al-'Ilmiyyah, 2000.

Keputusan Muzakarah Jawatankuasa Fatwa Majlis Kebangsaan Bagi Hal Ehwal Ugama Islam Malaysia Mengenai Isu-Isu Sains dan Perubatan. Kuala Lumpur: Jabatan Kemajuan Islam Malaysia. 2010.

Khairul Hamimah Mohammad Jodi \& Noor Hafizah Mohd Haridi. "Cabaran dan Pendekatan Dakwah Golongan LGBT: Satu Kajian di Pertubuhan Usrah Fitrah". Dalam Pembangunan Insan Kamil dalam Mendepani Era Milenia, eds. Nor Raudah Hj Siren et. al. Kuala Lumpur: Akademi Pengajian Islam Universiti Malaya, 2018: 289302.

Lacey, A.R. A Dictionary of Philosophy. London: Routledge, 1996.

Mahfudzah Mohamad, "Lesbian, Gay, Biseksual dan Transgender: Perspektif Undang-undang Jenayah Syariah," Jurnal Undang-undang dan Masyarakat. Bil. 19 (2015): 29-36.

Al-Makkī, Abū Țālib. Qūt al-Qulūb. Beirut: Dār al-Kitāb al-'Ilmiyyah, 1997. 
Al-Mandīlī, 'Abd al-Qādir. Penawar bagi Hati. Pattani: Sahabat Press, 1964.

McKinney, J.S., "On the Margins: A Study of the Experiences of Transgender College Students," Journal of Gay \& Lesbian Issues in Education. Bil. 3(1) (2005): 63-76.

Memahami Lesbian, Gay, Bioseksual dan Transgender Dari Perspektif Seorang Muslim. Putrajaya: Jabatan Kemajuan islam Malaysia (JAKIM) \& Yayasan Ihtimam Malaysia, t.th.

Mohd Hasrul Mohd Shuhari \& Mohd Fauzi Hamat, "AlMaqsad al-Asna Sebagai Sebuah karya Akidah alGhazali," Journal of Afkar Bil. 15 (2014): 1-44.

Mohd Shahril Othman. Psikospiritual Islam. Terengganu: Penerbit Universiti Sultan Zainal Abidin, 2014.

Al-Mudarrisí, Muḥammad Taqì. Al-Manțiq al-Islāmí: Ușūluh wa Manāhijuh. Kaherah: Dār al-Bayān li alTibā'ah wa al-Nashr, 1992.

Mukhtar Yahya. Pertumbuhan Akal dan Memanfaatkan Naluri Kanak-Kanak. Jakarta: Bulan Bintang, 1972.

Munsoor, Mohamed Safiullah \& Che Zarrina Saari, "Knowledge and Islam on the Non-Rational and Rational-Heart-Brain Inter-Connection: A Classical Islamic Scholarly Perspective," Journal of Afkar Bil. 19(1) (2017): 129-162.

Nik Muhd Marzuki $\mathrm{Hj}$. Mohd D. Nor. "Laporan pembentangan wakil JAWI di perjumpaan berkenaan lesbian, maknyah, biseksual dan trangender (transgender) dari sudut pendangan Islam bersama SUHAKAM," 2011.

Norafifah Ab Hamid, Nor Azlina Abd Wahab, Norajila Che Man, Mohd Nazim Ganti Shaari \& Pg Ismail Pg Musa, "Gejala Transgender di Malaysia: Sorotan Awal Kajian dari Perspektif Islam dan Undang-undang," Jurnal Penyelidikan Islam Bil. 27, (2015): 1-27. 
Norliah Sajuri, "Pertukaran Status Jantina Dalam Mykad dan Impikasinya," Jurnal Penyelidikan Islam Bil 19. (2006): 115-126.

PFlag Canada Inc., Understanding my Gay, Lesbian or Bisexual Parent, https://mycourses.mcgill.ca/webct.

Al-Qushayrī, Abū al-Qāsim 'Abd al-Karīm. Al-Risālah alQushayriyyah, ed. 'Abd al-Halīm Mạ̣mūd. Kaherah: Dār al-Khayr, 2003.

Roseliza Murni Ab. Rahman, "Kecelaruan Identiti Jantina: Perspektif Psikososial dan Biologi," Jurnal Psikologi dan Pembangunan Manusia, Bil. 19 (2003): 41-57.

Al-Sa'di, 'Abd al-Malik 'Abd al-Raḥmān. Sharh alNasafiyah fī al-'Aqīdah al-Islāmiyyah. Amman: Mața'ah al-Azhar, 2007.

Sharifah Basirah Syed Muhsin \& Che Zarrina Sa'ari, "Beberapa Aspek Psikoterapi Islam dalam Kitab Jawi, 'Penawar Bagi Hati' oleh Sheikh Abdul Qadir AlMandili," Journal of Afkar. Bil.14 (2013): 109-142.

Al-Shaybānì, Aḥmad bin Ḥanbal Abū 'Abd Allāh. Musnad al-Imām Ahmad Bin Hanbal. Kaherah: Mu'assasah Qurtubah, t.t.

Teh, Y.K., "Mak Nyahs (Male Transsexuals in Malaysia): The influence of Religion and Culture on Their Identity," International Journal of Transgenderism, Bil. 5(3) (2001): 1-13.

The Holy Bible, Douay-Rheims Version1609, 1582. http://triggs.djvu.org/djvueditions.com/BIBLES/DRV/Download.pdf

Wan Halim Othman. "Delima Mak Nyah di Dalam Masyarakat Malaysia.” Kertas Kerja Seminar Mak Nyah, Universiti Malaya, 24-25 Oktober 1987.

Wei, C.L., Azizan Baharudin, Raihanah Abdullah, Zuraidah Abdullah, Kathleen Por Chee Ern., "Transgenderism in Malaysia," Dharmaram Journals 37(1) (2012): 79-96. 
Zuraidah, Che Zarrina \& Chang "Transgenderisme di Malaysia: Pelan Bimbingan Kembali Kepada Fitrah," Afkār Vol. 20 Issue 2 (2018): 279-322

Yan Piaw, C. Kaedah dan Statistik Penyelidikan: Kaedah Penyelidikan. Malaysia: McGraw-Hill Education, 2006. Zikmund, W.G. Business Research Methods. Ohio: Thomson-South-Western, 2003.

Zubaidi Hj Ahmad, "Perbezaan Khunsa \& Transeksual," Majalah I. Bil. 147, 2015. 